\title{
Inhibitors of the Small Membrane (M) Protein Viroporin Prevent Zika Virus
}

\section{Infection}

Emma Brown ${ }^{1,2}$, Daniella Lefteri ${ }^{1}$, Ravi Singh ${ }^{2,3}$, Rebecca Thompson ${ }^{2,4}$, Daniel Maskell ${ }^{2,4}$, Hannah Beaumont $^{1,2}$, Matthew Bentham ${ }^{1,2}$, Gemma Swinscoe ${ }^{1,2,4}$, Andres Merits ${ }^{5}$, Claire Donald ${ }^{6}$, Alain Kohl $^{6}$, Andrew Macdonald ${ }^{2,4}$, Neil Ranson ${ }^{2,4}$, Richard Foster ${ }^{2,3}$, Clive S. McKimmie ${ }^{1 *}$, Antreas C. Kalli2,7*, and Stephen Griffin ${ }^{1,2 \#}$

1 - Leeds Institute of Medical Research, School of Medicine, Faculty of Medicine and Health, University of Leeds, St James' University Hospital, Beckett St., Leeds, LS9 7TF

2 - Astbury Centre for Structural and Molecular Biology, University of Leeds, Leeds, LS2 9JT

3 - School of Chemistry, Faculty of Maths and Physical Sciences, University of Leeds, Leeds, LS2 9JT

4 -School of Molecular and Cellular Biology, Faculty of Biological Sciences, University of Leeds, Leeds, LS2 9JT

5 - Faculty of Science and Technology, Institute of Technology, University of Tartu, Estonia

6 - MRC and University of Glasgow Centre for Virus Research, Sir Michael Stoker Building, Garscube Campus, 464 Bearsden Road, Glasgow, G61 1QH, Scotland (UK)

7 - Leeds Institute for Cardiovascular and Metabolic Medicine, Faculty of Medicine and Health, University of Leeds, Leeds, LS2 9JT

* contributed equally

\# address correspondence to s.d.c.griffin@leeds.ac.uk 


\section{$\underline{\text { Contact details }}$}

Emma Brown ${ }^{\mathfrak{s}}$ - bs13etb@leeds.ac.uk

Daniella Lefteri ${ }^{\top}$ - Daniella.Lefteri@glasgow.ac.uk

Ravi Singh ${ }^{\S}$ - ravi.singh@imperial.ac.uk

Rebecca Thompson - R.F.Thompson@leeds.ac.uk

Daniel Maskell - D.P.Maskell@leeds.ac.uk

Hannah Beaumont - um14hb@leeds.ac.uk

Matthew Bentham - M.J.Bentham@leeds.ac.uk

Gemma Swinscoe - G.E.Swinscoe@leeds.ac.uk

Andres Merits - andres.merits@ut.ee

Claire Donald - Claire.Donald@glasgow.ac.uk

Alain Kohl - Alain.Kohl@glasgow.ac.uk

Andrew Macdonald - A.Macdonald@leeds.ac.uk

Neil Ranson - N.A.Ranson@leeds.ac.uk

Richard Foster - R.Foster@leeds.ac.uk

Clive McKimmie - C.S.McKimmie@leeds.ac.uk

Antreas Kalli - A.Kalli@leeds.ac.uk

Stephen Griffin - S.D.C.Griffin@leeds.ac.uk

Present addresses:

§ - Covance Clinical and Periapproval Services Ltd, Otley Rd, Harrogate, HG3 1PY, UK

T - MRC and University of Glasgow Centre for Virus Research, Sir Michael Stoker Building,

Garscube Campus, 464 Bearsden Road, Glasgow, G61 1QH, Scotland (UK)

$\S$ - Room 301, Department of Chemistry, Molecular Sciences Research Hub, 82 Wood Lane, W12 OBZ, White City Campus, Imperial College London, UK 
Flaviviruses, including Zika virus (ZIKV), are a significant global health concern, yet no licensed antivirals exist to treat disease. The small M (Membrane) protein plays well-defined roles during viral egress, yet remains within virion membranes following release and maturation. However, it is unclear whether $\mathrm{M}$ plays a functional role in this setting. Here, we show that $\mathrm{M}$ forms oligomeric membranepermeabilising channels in vitro, with increased activity at acidic $\mathrm{pH}$ and sensitivity to the prototypic channel-blocker, rimantadine. In turn, rimantadine blocked an early stage of ZIKV cell culture infection.

Molecular dynamics (MD) generated rationalised structure-based channel models, comprising hexameric arrangements of dual trans-membrane protomers. Interestingly, His28 protonation increased channel opening, consistent with activation within acidifying endosomes. Models contained a predicted lumenal binding site for rimantadine, as well as a second target region on the membrane-exposed periphery. In silico screening enriched for repurposed drugs/compounds predicted to bind to one or other site. Multiple hits displayed potency in vitro and in cell culture, supporting the relevance of channel models. Finally, rimantadine effectively blocked ZIKV viraemia in a preclinical model, supporting that $\mathrm{M}$ constitutes a physiologically relevant antiviral target, for either repurposing rimantadine, or the development of new ZIKV therapies.

\section{6 words}


bioRxiv preprint doi: $h t t p s: / / d o i . o r g / 10.1101 / 2021.03 .11 .435022$; this version posted March 12, 2021. The copyright holder for this preprint (which was not certified by peer review) is the author/funder, who has granted bioRxiv a license to display the preprint in perpetuity. It is made available under aCC-BY-NC-ND 4.0 International license.

\section{Introduction}

Zika virus (ZIKV) was first isolated in the eponymous Ugandan forest in 1947 and is a mosquitoborne arbovirus (arthropod-borne), classified within the Flavivirus genus of the Flaviviridae 1 , 2). Historically, ZIKV caused infrequent and relatively mild infections in humans with symptoms comprising fever, rash, headaches, joint/muscle pain and conjunctivitis(3). However, once confined to Africa and South East Asia, a large outbreak in 2007 on Yap Island (Micronesia), followed by further outbreaks in French Polynesia, New Caledonia, and the Cook Islands in 2013/14, signified spread of the virus across the Pacific. The virus then arrived in Brazil in 2015, where an epidemic affecting $>1 \mathrm{M}$ people ensued. This resulted in worldwide spread of the virus involving more than eighty countries and signified emergent ZIKV as a global health concern(4).

Worryingly, the outbreaks in Yap and thereafter encompassed considerably more serious symptomology, which has been linked to evolution of New World ZIKV strains(5). This included more serious and frequent neurological complications, increased incidence of Guillian-Barre Syndrome, and a devastating epidemic of microcephaly in new-borns where maternal infection had occurred during the first trimester of pregnancy $(6-8)$. Eventually, the outbreak was contained by surveillance combined with control of insect vectors, predominantly Aedes aegypti and Aedes albopictus mosquitos(9). More than five years later, a ZIKV vaccine remains elusive, although several are in trials (reviewed in (10)). Similarly, no licensed antiviral therapies exist to treat ZIKV infection, yet repurposing of nucleotide analogue inhibitors of the NS5 protein shows promise(11-13).

ZIKV, like other Flaviviruses, possesses a positive sense single-stranded RNA (ssRNA) genome over ten kilobases in length, capped at the $5^{\prime}$ end by a methylated dinucleotide ( $\left.\mathrm{m}^{7} \mathrm{GpppAmp}\right)(14$, 15). The RNA is translated into a polyprotein that is subsequently cleaved by host and viral proteases to yield ten mature gene products(16); these are spatially organised into structural virion components at the $\mathrm{N}$-terminus, and non-structural replicase proteins at the C-terminus. The mature enveloped virion comprises the viral RNA, the capsid $(C)$ protein and two membrane proteins: envelope $(E)$ and the small membrane $(\mathrm{M})$ protein $(17,18)$. Virions undergo maturation as they traffic through the cell during egress, with $\mathrm{M}$ and the precursor (pr) peptide acting as chaperones for the $\mathrm{E}$ protein(19). Maturation occurs upon furin-mediated cleavage of $\mathrm{pr}-\mathrm{M}$ in the $\operatorname{Golgi}(20,21)$, although this has 
bioRxiv preprint doi: https://doi.org/10.1101/2021.03.11.435022; this version posted March 12, 2021. The copyright holder for this preprint (which was not certified by peer review) is the author/funder, who has granted bioRxiv a license to display the preprint in perpetuity. It is made available under aCC-BY-NC-ND 4.0 International license.

variable efficiency $(22,23)$. The cleaved pr peptide remains associated with $\mathrm{E}$, preventing exposure of the fusion loop within acidifying secretory vesicles. Release from the cell into a pH-neutral environment leads to the loss of pr and resultant structural rearrangement of $E$ and $M(24)$. Whilst $E$ comprises the essential virus attachment and entry protein, the role of $\mathrm{M}$ within the mature infectious virion remains unknown(25).

The presence of dimeric $\mathrm{M}$, bound to $\mathrm{E}$ dimers(25), within the virion raises the question of whether it might play a role during the virus entry process. Unfortunately, cryo-EM structures of acidified Flavivirus particles - a proxy for changes likely to occur during endocytosis - do not contain density attributable to the $\mathrm{M}$ protein(26). Moreover, $\mathrm{E}$ undergoes a shift from a dimeric to a trimeric form thought to mediate membrane fusion(27-31). This presumably disrupts E-M dimeric interactions, thereby allowing $\mathrm{M}$ an opportunity to also adopt alternative conformations and explore other oligomeric states.

Interestingly, dengue virus (DENV) M peptides formed membrane channels in vitro(32), which would require the formation of higher order oligomers. However, electrophysiology studies in Xenopus oocytes failed to detect $M$ mediated proton conductance(33). Nevertheless, due to its size and hydrophobicity, M has long been speculated to comprise a virus-encoded ion channel, or "viroporin", typified by the M2 proton channel of influenza A virus (IAV)(34-36). M2 functions to allow protons to pass into the virion core during virus entry, enabling the uncoating of viral RNA, and is the target of the antiviral drugs amantadine and rimantadine, setting clinical precedent for viroporins as drug targets.

Here, we provide evidence that ZIKV M forms rimantadine-sensitive, oligomeric membrane channels whose activity increases at acidic $\mathrm{pH}$. Rimantadine blocks an early step during the ZIKV life cycle, consistent with a role for $\mathrm{M}$ channels during virus entry. Critically, rimantadine also abrogates viraemia within in vivo ZIKV preclinical models, supporting that $\mathrm{M}$ channel activity is a physiologically relevant target. In-depth molecular dynamics investigations support that $\mathrm{M}$ channels are comprised of hexameric complexes, with the channel lumen lined by the C-terminal trans-membrane domain (TMD). Ensuing models provided an effective template for in silico high throughput screening (HTS) of a library of FDA-approved and other biologically active compounds, targeting two discrete sites 
bioRxiv preprint doi: https://doi.org/10.1101/2021.03.11.435022; this version posted March 12, 2021. The copyright holder for this preprint (which was not certified by peer review) is the author/funder, who has granted bioRxiv a license to display the preprint in perpetuity. It is made available under aCC-BY-NC-ND 4.0 International license.

on the channel complex. Pleasingly, enrichment of the library led to the identification of muchimproved blockers of $\mathrm{M}$ channel activity, laying the foundation for potential drug repurposing alongside bespoke antiviral development. 
bioRxiv preprint doi: https://doi org/10.1101/2021.03.11.435022; this version posted March 12, 2021. The copyright holder for this preprint (which was not certified by peer review) is the author/funder, who has granted bioRxiv a license to display the preprint in perpetuity. It is made available under aCC-BY-NC-ND 4.0 International license.

\section{Results}

\section{ZIKV M peptides form oligomeric complexes within membrane-mimetic environments}

M protein resides as a dimeric form resolvable within cryo-EM structures of mature ZIKV, and other Flavivirus particles, in close association with $\mathrm{E}$ dimers(25). Thus, M would be required to form higher order oligomers to form a putative channel across the membrane. This might conceivably occur during endocytosis where acidic $\mathrm{pH}$ induces reconfiguration of $\mathrm{E}$ into a trimeric fusion complex, presumably also liberating $M$ dimers to move within the virion membrane(27-31). Thus, we hypothesised that $M$ peptides should form channel structures within a lipidic environment in the absence of E protein.

A peptide lacking the disordered $\mathrm{N}$-terminal 20 amino acids was synthesised based upon the $\mathrm{M}$ protein sequence from a New World ZIKV isolate (PE243)(37). Peptides therefore comprised the three helical regions of the mature $M$ protein, the second and third of which form TMDs within virion membranes (Figure 1a, b, c, S1). Peptides were reconstituted using several non-ionic detergents used frequently as membrane-mimetics in structural and/or biophysical studies(38-41), as well as in our previous investigations of viroporin oligomerisation(42-45). Visualisation of peptide-detergent complexes using native PAGE revealed that dihexanoyl-phosphatidylcholine $\left(\mathrm{DH}_{6} \mathrm{PC}, 300 \mathrm{mM}\right)$ induced the formation of higher order oligomers (Figure 1d). A dominant species of $\sim 45-50 \mathrm{kDa}$ formed along with another less abundant assemblage in the region of $\sim 60 \mathrm{kDa}$, although it is not possible to assign precise molecular weights by this method. However, this was consistent with the potential formation of hexameric and/or heptameric oligomers, and confirmed that dimers were not the only multimeric conformation adopted by the M protein.

\section{ZIKV M peptides exhibit acid-enhanced channel activity with sensitivity to rimantadine}

Given the formation of higher oligomers, we next assessed whether M peptides exhibited membrane permeabilisation using an indirect assay for channel formation, based upon the release and unquenching of fluorescent dye from liposomes. This assay has been used to characterise the 
bioRxiv preprint doi: $h$ ttps://doi org/10.1101/2021.03.11.435022; this version posted March 12 2021. The copyright holder for this preprint (which was not certified by peer review) is the author/funder, who has granted bioRxiv a license to display the preprint in perpetuity. It is made available under aCC-BY-NC-ND 4.0 International license.

activity of several other viroporins and can be adapted to both explore aspects of channel biochemistry as well as identifying small molecule inhibitors of channel activity(42-51).

Dose-dependent dye release occurred using sub-micromolar concentrations of $\mathrm{M}$ peptide, consistent with channel forming activity (Figure 1e); $780 \mathrm{nM}$ was chosen as an optimal concentration for ensuing investigations. Interestingly, mildly acidic $\mathrm{pH}$ conditions increased M-mediated release of carboxyfluorescein (CF), reminiscent of influenza A virus (IAV) M2(48), hepatitis C virus (HCV) p7 $(50,52)$ and human papillomavirus type 16 (HPV16) E5(44) in similar experiments (Figure 1f). Such conditions mimic those found within endocytic vesicles, consistent with $\mathrm{M}$ channels potentially being activated during virus entry.

Finally, we tested whether $M$ channel activity was sensitive to inhibitory small molecules, indicative of the formation of structurally ordered complexes. Moreover, prototypic channel blockers can identify druggable sites within viroporin complexes, amenable to the further identification of improved small molecules $(46,48,49)$. Rimantadine $(1 \mu \mathrm{M})$ caused a significant reduction in M channel activity (Figure 1g), consistent with the presence of a viable binding site within a soluble, folded M channel complex.

\section{M protein forms channel-like oligomeric complexes}

We reasoned that rimantadine-sensitive dye release from liposomes should be consistent with the formation of discrete membrane channels comprising at least four M protomers, likely more based upon migration during native PAGE (Figure 1d). To investigate the nature and stoichiometry of $M$ complexes, $\mathrm{DH}_{6} \mathrm{PC}$ solubilised $\mathrm{M}$ peptides were immobilised upon carbon grids and negatively stained using uranyl acetate over a range of detergent concentrations. Unfortunately, use of $300 \mathrm{mM}$ detergent prevented the efficient adhesion of peptides, yet visualisation of $\mathrm{M}$ complexes at lower concentrations revealed the formation of circular structures, the majority of which were oriented approximately in parallel with the grid plane (Figure 2a).

Interestingly, complexes exhibited a significant degree of structural heterogeneity (Figure $2 \mathrm{~b}$, top panel), although separable class subsets were resolvable amongst $>9000$ complexes analysed at 
$150 \mathrm{mM}$ detergent (Figure 2b, bottom panel). Unfortunately, the degree of heterogeneity and small size prevented determination of stoichiometry by $2 \mathrm{D}$ rotational averaging. Nevertheless, the absence of obvious aggregation and the formation of, albeit heterogeneous, channel-like structures supports that $\mathrm{M}$ is capable of adopting conformations corresponding to membrane-spanning channel complexes.

\section{Rimantadine inhibits ZIKV infectivity in cell culture}

We hypothesised that if $M$ protein-mediated channel activity observed in vitro was relevant during the ZIKV life cycle, then rimantadine would exert an antiviral effect. We therefore tested the ability of rimantadine to inhibit ZIKV infection of Vero cells, adding the drug both during infection and for the ensuing $24 \mathrm{hr}$ period prior to analysis. Rimantadine exerted a dose-dependent reduction in ZIKV infection, assessed by both the number of cells infected as well as viral protein production (Figure 3a, b, c). Infected cell numbers underwent statistically significant reductions at rimantadine concentrations of $10 \mu \mathrm{M}$ and above. Importantly, rimantadine affected neither cell viability, nor the uptake of fluorescently labelled EGF as a proxy marker for clathrin-mediated endocytosis over the concentration range tested (Fig S2).

We next added rimantadine $(80 \mu \mathrm{M})$ during different stages of the infection process, measuring drug effects by a BHK cell plaque-reduction assay, to determine the approximate stage of the ZIKV life cycle affected. Significant reductions of infectivity occurred when rimantadine was present during infection, with more pronounced effects upon pre-incubating cells with the drug (Figure $3 d$ ). Measurable, but non-significant reductions also occurred upon adding rimantadine only prior to infection, or during and following infection. Taken together, rimantadine affected an early stage of the virus life cycle, coincident with virus entry.

\section{Free M protomers retain a double trans-membrane topology}

The structure of $\mathrm{M}$ within mature ZIKV and other Flavivirus virion cryo-EM reconstructions is a dimeric complex of double-TMD protomers, closely associated with the TMDs of adjacent E 
bioRxiv preprint doi: https://doi org/10.1101/2021.03.11.435022; this version posted March 12, 2021. The copyright holder for this preprint (which was not certified by peer review) is the author/funder, who has granted bioRxiv a license to display the preprint in perpetuity. It is made available under aCC-BY-NC-ND 4.0 International license.

dimers(25). The relatively short TMDs within M cause a pinching of the virion membrane bilayer, reducing its thickness by several $\mathrm{nm}(21,53,54)$.

$\mathrm{M}$ is well conserved between ZIKV isolates, and regions including the linker region between the first and second alpha helices are shared with other Flaviviruses (Figure 1a). Where sequence conservation is absent, secondary structure and amino acid similarity are maintained (Figure 1b). However, four different TMD prediction software packages revealed disparate outputs for the region known to form the second and third helices within cryo-EM reconstructions, with two favouring the formation of an extended single TMD (Figure S3a). Interestingly, the MEMSAT-SVM package not only predicted a double TMD topology, but also that helix three displayed properties consistent with being pore lining (Figure S3b).

Thus, we undertook molecular dynamics simulations to address whether $M$ in the absence of potentially stabilising interactions with $E$ dimers might flip from a double, to a single TMD conformation. Monomeric M protein was placed within model POPC bilayers (Figure 4a), starting as either the cryo-EM derived conformer, or one where the two TMDs were straightened into a membrane-spanning helix containing a small unstructured region between helix two and three (Figure 4b). Simulations of the two species within a POPC lipid bilayer revealed that the single helix rapidly began to revert to a hairpin-like structure (Figure 4c, d). Thus, it is likely that higher order $\mathrm{M}$ oligomers would also comprise double-TMD protomers.

\section{The $\mathrm{N}$-terminal extra-membranous helix regulates formation of predicted $\mathrm{M}$ dimers}

Virion associated $\mathrm{M}$ dimers are arranged in close proximity to the $\mathrm{E}$ protein, with interactions evident between the $M N$-terminus and $E$ thought to stabilise the complex $(21,25)$ (Figure 5a). However, upon acidification, E rearranges to form a trimeric fusion complex, presumably liberating $\mathrm{M}$ to diffuse within the membrane; M electron density has not been resolved within structures of acidified mature Flavivirus virions(26).

Thus, we hypothesised that M may self-associate as different conformers, dependent upon whether the $\mathrm{N}$-terminus was able to move freely. Two $\mathrm{M}$ protomers were placed at a distance within bilayers 
bioRxiv preprint doi: https://doi.org/10.1101/2021.03.11.435022; this version posted March 12, 2021. The copyright holder for this preprint (which was not certified by peer review) is the author/funder, who has granted bioRxiv a license to display the preprint in perpetuity. It is made available under aCC-BY-NC-ND 4.0 International license.

and multiple simulations carried out, either with a rigidified N-terminus emulating an E-bound form, or where the region was flexible. To achieve a rigidified N-terminus an elastic network was applied to the protein that did not allow any conformational changes within the protein during the simulations. M was capable of forming at least five different dimeric conformations, including one resembling the structure within mature virions ("type I"), and another where the potential pore-forming C-terminal helices were aligned ("type III") (Figure 5b, c, S4). Interestingly, rigidified protomers adopted type I conformers more frequently, whereas the flexible protein primarily adopted a type III conformation where the third helices are aligned (Figure $5 \mathrm{~d}$ ). Thus, the $\mathrm{N}$-terminal helix appears to play a role in organising the orientation of protomers interacting within the virion membrane, and this may reflect interactions, or lack thereof, with E following acidification.

\section{Molecular dynamics simulations favour the formation of compact hexameric channel complexes}

Observations from native PAGE and electron microscopy, combined with the preference for unrestricted protomers to form type III dimers during simulations, led us to construct both hexameric and heptameric models of $M$ channels with helix 3 lining the channel lumen (Figure 6, S5, S6, annexe); this helix was predicted to display pore-lining properties based upon analysis using MEMSAT-SVM (see above and Figure S3). We modelled two different hexameric arrangements (Figure 6, S5, S6): in the first arrangement, helix one was orientated almost perpendicular to the channel pore with helix three facing towards the pore (radial). For the second model, the protein was rotated clockwise by 20 degrees to significantly increase the number of inter-protomer contacts within a more compact structure (compact). The second conformation included interactions between the extra-membranous helix one, as seen during class III dimer interactions. Anti-clockwise rotation was not possible due to stearic hindrance. We also generated radial and compact hexamer and heptamer models with helix two lining the pore, ensuring that other potential conformations were explored (see annexe). However, hexamer models where helix two lined the pore collapsed rapidly upon simulation, whereas heptamers lined by either helix showed an inability to close in the majority of the simulations (Annexe). Moreover, radial hexamers lined by helix three either closed rapidly 
bioRxiv preprint doi: https://doi.org/10.1101/2021.03.11.435022; this version posted March 12, 2021. The copyright holder for this preprint (which was not certified by peer review) is the author/funder, who has granted bioRxiv a license to display the preprint in perpetuity. It is made available under aCC-BY-NC-ND 4.0 International license.

within the simulation $(6,40 \mathrm{~ns})$ or not at all (>200 ns). In the two channels that closed, one of the subunits moves to the centre of the channel to occupy the pore (Annexe). This again was inconsistent with the formation of a stable channel complex.

By contrast, simulations supported that the compact hexameric model with helix three lining the lumen is likely to comprise the best physiological representation of a channel structure formed by $\mathrm{M}$ protein (Figure 6, 7). The compact channel structure retained a lumen with a radius of $5.233 \AA$ at its narrowest point, lined by Thr57, Val61, Ile62, Val65, Met66, Leu68 and Leu69. Upon 200 ns atomistic simulation within a model POPC bilayer, channels closed at Leu64 and Leu68, despite the former not facing the lumen at the beginning of the simulation (Figure 6). Channel closing first occurred at 70, 80 and 176 ns within three separate simulations, with channels remaining closed for the remainder of the simulation (Figure $6 a, b$ ). Thus, despite the starting position of this model possessing a relatively wide lumen compared with the diameter of a water column $(\sim 1.15 \AA)$, compact $\mathrm{M}$ hexamer models lined by helix three displayed spontaneous closure consistent with a reliable physiological representation of a membrane channel.

\section{Influence of the N-terminal helix and His28 protonation upon hexameric M complexes}

Data from dye release assays and the role early during the ZIKV life cycle were consistent with the hypothesis that acidic $\mathrm{pH}$ might activate $\mathrm{M}$ channels during endocytosis. Interestingly, the only protonatable residue at physiological $\mathrm{pH}$ within the $\mathrm{E}$ peptide was His28, present within helix I. This placed His28 $16.8 \AA$ from the centre of the channel lumen, yet the extensive interactions formed by helix one in compact models made it conceivable that modification of this residue might exert an influence upon overall channel behaviour. By contrast, radial models placed His28 $31.28 \AA$ from the lumen, further supporting the relevance of compact models. (Figure 6, 7, S6, Annexe).

His28 was modified by dual protonation, mimicking the predicted effect of endosomal acidification (Figure 7). This had seemingly little effect upon the starting structure compared to normal conditions, with the narrowest lumenal diameter being 5.233 compared with $5.207 \AA$ (Figure S6a). Nevertheless, protonated channel complexes took longer to close during three 200 ns simulations compared to the 
bioRxiv preprint doi: https://doi.org/10.1101/2021.03.11.435022; this version posted March 12, 2021. The copyright holder for this preprint (which was not certified by peer review) is the author/funder, who has granted bioRxiv a license to display the preprint in perpetuity. It is made available under aCC-BY-NC-ND 4.0 International license.

native model: 100, 130 and >200 ns (Figure 7). This supported that compact hexameric M channels lined by helix three are capable of responding to acidified environments. Interestingly, the channel that failed to close after 200 ns retained a lumenal radius of $2.533 \AA$, compared to $5.233 \AA$ for the starting conformation (Figure S6b). It is possible that this better-reflects a physiologically relevant channel conformation compared to the starting structures, but further simulations will be necessary to test this hypothesis. Protonated channels closed in a similar manner to native complexes; Val61, Leu64, Val65 and Leu68 occluded the pore, along with lle62 in the protonated state (Figure 7b, c). This supports that His28 protonation modulates native channel gating, rather than inducing aberrant behaviour within the oligomeric structure.

Finally, we examined the importance of helix one for maintaining a stable channel given the apparent role of His28 and the extensive interactions formed in the compact structure. Strikingly, removal of helix one caused the collapse of stable pores within 50 ns in each of three simulations (Figure $7 d$ ). Thus, $M$ channels seemingly differ from viroporins such as M2 where the TMD appears to determine much of the stability for the helical bundle formed within the membrane. Moreover, helix one appears to constitute a functional switch, influencing $M$ dimerisation whilst either rigidified by $E$ interactions or moving freely, as well as determining both the stability and gating of ensuing channel complexes.

\section{Identification of two potential druggable sites within hexameric M complexes}

We hypothesised that molecular dynamics-derived hexamer models might retain sufficient accuracy to both understand and improve upon the inhibitory action of rimantadine. Whilst this drug exerted a genuine antiviral effect, its relatively low potency in cell culture was reminiscent of its promiscuous activity against other viroporins $(44,47,48)$. Nevertheless, the action of rimantadine both in vitro and in vivo implied that at least one physiologically relevant druggable binding site exists within the $M$ channel complex.

Docking of rimantadine into the compact $\mathrm{M}$ hexamer model revealed an energetically favourable interaction with a lumenal binding site in close proximity to the region in which channel closure occurred during simulations (Figure 8a). The adamantyl cage of rimantadine made predicted 
bioRxiv preprint doi: https://doi.org/10.1101/2021.03.11.435022; this version posted March 12, 2021. The copyright holder for this preprint (which was not certified by peer review) is the author/funder, who has granted bioRxiv a license to display the preprint in perpetuity. It is made available under aCC-BY-NC-ND 4.0 International license.

hydrophobic contacts with Val61, Ile62, Leu64, Val65 and Leu68, leaving the methyl group and amine solvent exposed, projecting into the channel lumen. The same site also underwent predicted interactions with other adamantyl-containing molecules, including amantadine, which adopted a similar predicted binding mode to rimantadine (Figure 8b, c). However, both methyl- and acetylrimantadine reversed the orientation of the adamantyl cage such that the polar group interacted with lumenal residues (Figure 8c).

Reassuringly, the lumenal rimantadine site (L1) was the most favourable in terms of druggability score for the compact hexamer model, assessed using the SiteMap programme (Maestro, Schrödinger). Two other potential lumenal sites were also identified with lower predicted druggability scores (L2, L3, Figure 8a). However, inspection of the $M$ channel model identified an additional region upon the membrane-exposed periphery that could also undergo interactions with small molecules (P1, Figure 8a). Such binding sites are less likely to be identified computationally due to the high solvent exposure of potential ligands, yet such sites have been successfully targeted for other viroporins $(48,49)$.

To explore the potential relevance of the P1 site, we exploited a defined series of compounds developed targeting a similar site upon the HCV p7 channel complex. The planar structure of these compounds is more consistent with the shape of the P1 site compared to L1, as supported by the predicted in silico modelling. Encouragingly, two of the seven compounds tested displayed inhibitory effects versus $M$ in dye release assays, with JK3/42 being most active (Figure $8 d$ ). Unfortunately, additional adamantane derivatives with bulkier $\mathrm{R}$ groups were ineffective at targeting $\mathrm{M}$ activity (Figure S7), potentially due to the limited size of the L1 cavity. Thus, inhibitor effects and docking data supported the presence of more than one distinct druggable binding site within $\mathrm{M}$ complexes, to exploit via novel chemical series.

\section{In silico screening enriches for improved repurposed $M$ channel inhibitors}

We next investigated whether in silico screening could identify and enrich for compounds predicted to interact with L1 and/or P1, with a view to developing two complementary inhibitor series. L1 was 
bioRxiv preprint doi: https://doi.org/10.1101/2021.03.11.435022; this version posted March 12, 2021. The copyright holder for this preprint (which was not certified by peer review) is the author/funder, who has granted bioRxiv a license to display the preprint in perpetuity. It is made available under aCC-BY-NC-ND 4.0 International license.

defined as the site comprising Val61, Leu64, Val65 and Leu68, and P1 by Tyr63, Leu64, Val65, Met66, Ile67 and Leu68. The two sites effectively represented the internal and external face of a single region within the channel complex, which is also involved during channel closing in simulations and centred upon Leu68. The convergence of these three regions was suggestive of their importance in being able to influence channel gating (Figures 7c, 8a, 8b).

To determine whether compounds with drug-like properties could target the L1 and P1 sites, we employed a screening library comprised of FDA-approved, generic, and other compounds with proven biological activity. In silico screening of 1280 compounds (TocrisScreen https://www.tocris.com/product-type/tocriscreen-compound-libraries) was undertaken using Glide (Schrödinger) and a rank-order list generated for each site following attrition and removal of compounds common to both sites. A short-list of 50 compounds targeting each site was generated for subsequent validation in vitro using dye release assays (Table 1,2). Note, predicted docking scores are not directly comparable between $\mathrm{P} 1$ and L1 owing to binding penalties incurred at the P1 site discussed above.

Dye release assay screens (96-well format) were conducted using compounds at a concentration of one micromolar, with positive hits defined as compounds exerting a $50+/-5 \%$ decrease in M activity (Figure S8). Twenty-four hits were identified from the L1-targeted short-list, and fifteen for the P1 site.

We selected three compounds from each list, based upon both potency and commercial availability, for validation in plaque-reduction assays. As the components of the repurposing library predominantly target cellular factors, MTT assays determined maximal concentrations prior to the development of cytotoxicity for each compound (Figure S9). Testing at these concentrations revealed that each of the compounds exerted a statistically significant reduction upon ZIKV infectivity, with the most effective showing sub-micromolar potency (Figure 9a, b). Two L1-selected compounds, KB SRC 4 and GNF 5837 displayed antiviral efficacy at 250 and $80 \mathrm{nM}$, respectively, whereas the most effective P1-targeted compound, AA 29504, was active at ten micromolar. Examination of the predicted binding pose for these compounds and the L1/P1 sites revealed that both molecules underwent additional interactions with regions adjacent to the core binding sites 
(Figure 9c-f). GNF 5837, an inhibitor of the tropomyosin receptor kinase (TRK) family, is predicted to make extended contacts within the lumen, including with two of the predicted rimantadine binding sites, stabilised by H-bonding between a carbonyl and Thr57 (Figure 9d).

The considerable enrichment for potency, compared to rimantadine, seen amongst compounds selected by in silico screening supports the validity of MD models and their use as potential templates for rational drug development.

\section{Rimantadine prevents ZIKV viraemia in vivo}

We assessed rimantadine antiviral effects in vivo using a preclinical ZIKV infection model(55) comprising C57BL/6 mice and transient blockade of the interferon alpha receptor type 1 (IFNAR1). This allows the establishment of robust infection within an immunocompetent host, and does not lead to the severe sequelae seen within immunodeficient systems. Moreover, the model incorporates improved physiological relevance via concomitant biting at the inoculation site by female Aedes aegypti mosquitos, which enhances the efficiency of infection (Figure 10a).

Ten C57BL/6 mice received a sub-cutaneous dose of $20 \mathrm{mg} / \mathrm{kg}$ rimantadine (or carrier control), 30 min prior to ZIKV infection ( $10^{3}$ plaque forming units, pfu) by injection into the dorsal side of one hind foot, immediately following exposure to up to five mosquito bites. A second bolus of rimantadine was administered $5 \mathrm{hr}$ post-infection. Animals were sacrificed and processed $24 \mathrm{hr}$ post-infection, harvesting tissue from the inoculation site as well as blood via cardiac puncture. RT-qPCR analysis confirmed equivalent copies of viral RNA present within tissues at the inoculation site (Figure 10b), whereas viraemia was dramatically reduced within rimantadine treated animals, measured by BHK cell plaque assay (Figure 10c). Thus, rimantadine exerted an antiviral effect in vivo that prevented dissemination of the virus, consistent with cell culture observations, supporting the druggability of $M$ in vivo. 
bioRxiv preprint doi: https://doi.org/10.1101/2021.03.11.435022; this version posted March 12, 2021. The copyright holder for this preprint (which was not certified by peer review) is the author/funder, who has granted bioRxiv a license to display the preprint in perpetuity. It is made available under aCC-BY-NC-ND 4.0 International license.

\section{Discussion}

This work supports that the mature M protein residing within the mature ZIKV virion acts as an ion channel with a critical function during virus entry. This is reminiscent of the IAV M2 protein, which responds to endosomal $\mathrm{pH}$ to allow protonation of the virion core, expediting virion uncoating(56); we have recently demonstrated that $\mathrm{HCV}$ p7 plays a similar role(49). Moreover, like M2, the activity of $\mathrm{M}$ is sensitive to both prototypic small molecules and rationally designed ligands, preventing infection both in cell culture and in vivo. Thus, $\mathrm{M}$ channels represent a potential new target for antiviral therapies that could both limit disease severity and engender prophylactic use to disrupt transmission.

$M$ resides as E-associated dimers within the mature virion(25), yet the formation of $M$ channels requires the assembly of higher order structures in the membrane to generate an aqueous pore. However, the formation of trimeric $\mathrm{E}$ complexes during acid-induced fusion provides an opportunity for $M$ to rearrange and adopt alternative conformations. Density corresponding to $M$ is absent from cryo-EM reconstructions of acidified mature Flavivirus virions, which are themselves inherently unstable and require the binding of E-specific FAb fragments to preserve their architecture(26). It is possible that asymmetric formation of relatively few channel complexes leads to a loss of signal upon application of icosahedral symmetry, or due to the overwhelming inherent symmetry of the particle. It would be of interest to apply symmetry expansion or focused classification techniques to acidified virions to investigate this possibility.

$M$ protein was previously proposed to function as a viroporin based primarily upon its size and hydrophobicity, yet conclusive evidence for a defined role within Flavivirus life cycles has been lacking. C-terminal $M$ derived peptides from DENV type 1 were shown to form cation-selective channels in suspended bilayers(32), with sensitivity to amantadine $(10 \mu \mathrm{M})$ and higher concentrations hexamethylene amiloride $(100 \mu \mathrm{M})$. However, a subsequent study using a series of pr-M protein expression constructs with additional $\mathrm{N}$-terminal signal peptides and myc epitope tags failed to demonstrate $\mathrm{pH}$ activated channel activity in Xenopus laevis oocytes(33). Nevertheless, in addition to the difficulties interpreting negative data, it was unclear whether proteins derived from these constructs underwent authentic proteolytic processing to enable trafficking of mature M protein 
bioRxiv preprint doi: https://doi.org/10.1101/2021.03.11.435022; this version posted March 12, 2021. The copyright holder for this preprint (which was not certified by peer review) is the author/funder, who has granted bioRxiv a license to display the preprint in perpetuity. It is made available under aCC-BY-NC-ND 4.0 International license.

to the oocyte membrane. Older studies showed that DENV replication in human peripheral blood leukocytes and Rhesus macaque kidney epithelial cells (LLC-MK2) was suppressed by amantadine and rimantadine, with maximal effect when drugs were administered concomitant with infection(57), reminiscent of findings herein.

Consistent with the formation an aqueous pore across the membrane, ZIKV M peptides migrated as higher order structures when reconstituted in the membrane-mimetic detergent, $\mathrm{DH}_{6} \mathrm{PC}$. These corresponded to potential hexamers or heptamers, estimated by native PAGE, and were confirmed to adopt a channel-like architecture using TEM. However, heterogeneity prevented determination of precise stoichiometry by rotational averaging. Nevertheless, M complexes mediated membrane bilayer permeability using an indirect ion channel assay, based upon fluorescent dye release from liposomes. Dose-dependent dye release was not only increased by acidic $\mathrm{pH}$, but was also sensitive to rimantadine. Importantly, rimantadine sensitivity supports that dye release was mediated by interactions with a folded protein complex rather than via aggregates disrupting membrane integrity, and increased activity at acidic $\mathrm{pH}$ is consistent with activation within acidifying endosomes during virus entry. Other pH-gated channels including IAV M2, HCV p7 (genotype and polymorphismdependent) and HPV E5, are similarly activated within the same assay system(44, 48, 49, 52).

Rimantadine was similarly able to interrupt ZIKV infection within Vero cells, causing a dosedependent reduction in the number of cells infected and ensuing virus protein expression. The $\mathrm{EC}_{50}$ for rimantadine was between $10-20 \mu \mathrm{M}$, which is comparable to drug potency versus susceptible HCV strains(47). Rimantadine was most effective when added prior to and simultaneously with infectious innoculae, suggesting that pre-loading of endocytic vesicles with the drug may expedite the inhibition of virion-resident channels. Interestingly, adding rimantadine both during and after infection was consistently less effective than adding it during the infection alone. We are uncertain why this should be the case, yet we speculate that in addition to inhibitory properties, rimantadine may also exert a drug rescue effect upon cells during multi-cycle replication, lessening the cytopathic effects of ZIKV infection and thereby artificially inflating the number of surviving cells remaining at the end of the assay. 
bioRxiv preprint doi: https://doi.org/10.1101/2021.03.11.435022; this version posted March 12, 2021. The copyright holder for this preprint (which was not certified by peer review) is the author/funder, who has granted bioRxiv a license to display the preprint in perpetuity. It is made available under aCC-BY-NC-ND 4.0 International license.

However, rimantadine also potently suppressed ZIKV replication in a preclinical model, supporting that $\mathrm{M}$ channels constitute a physiologically relevant drug target. Rimantadine treatment prevented viraemia, consistent with an effect upon virus spread linked to drug effects observed in culture. To our knowledge, with the exception of IAV M2, this is the only example where targeting a viroporin has been shown to exert preclinical antiviral efficacy, and so strongly supports that $M$ channels are a physiologically relevant drug target.

In lieu of structural information for channel complexes, we employed molecular modelling and molecular dynamics simulations to understand how channels might be formed from either dimeric or monomeric M protein. Importantly, simulations supported the formation of dual-membrane spanning topology protomers, as seen within the mature virion(25). This was despite individual prediction packages, as used in other studies, supporting that $\mathrm{M}$ formed single-pass structures. Moreover, the $\mathrm{N}$-terminal helix one exerted a strong influence upon the formation of $\mathrm{M}$ dimers, with virion-derived conformers formed when the helix was rigidified to emulate interactions with E. In this scenario, dimers formed primarily as seen in mature virion cryo-EM structures, whereas a free-moving $\mathrm{N}$ terminus enriched for the formation of dimers with aligned helix three, consistent with the prediction that this helix is pore lining using MEMSAT-SVM. Thus, the formation of channel complexes within the acidifying virion membrane following dissociation of $M-E$ interactions would be unlikely to require energetically unfavourable rearrangements of M topology.

Compact hexameric models for $\mathrm{M}$ channel complexes displayed consistent channel-like characteristics compared to radially arranged hexamers, or heptameric models in either conformation, with His28 protonation increasing the propensity of channels to remain open during simulations. Moreover, helix one was essential for the stability of these complexes within simulated membranes. Channels closed around a conserved Leu64 residue, closing off the water column and thus preventing the flow of ions. It is unclear how His28 protonation influences this process, although it may serve to counteract the overall net basic +1 charge found within helix one. In addition, the unstructured region omitted from peptides and simulations also carries a net basic charge along with a His7 residue that is highly conserved amongst other Flaviviruses. 
bioRxiv preprint doi: https://doi.org/10.1101/2021.03.11.435022; this version posted March 12, 2021. The copyright holder for this preprint (which was not certified by peer review) is the author/funder, who has granted bioRxiv a license to display the preprint in perpetuity. It is made available under aCC-BY-NC-ND 4.0 International license.

Whilst a blunt tool in terms of potency, rimantadine binding can signify druggable binding sites within viroporin complexes $(46,48,49)$. Rimantadine was predicted to bind within a lumenal cavity in close proximity to Leu64, repeated along the six-fold radial symmetry of the channel model, and the external membrane exposed face of same region within the channel also contained a cavity into which small molecules were predicted to bind. Excitingly, the presence of both lumenal and peripheral binding sites for small molecules could enable future M-targeted drug combinations that might minimise the chance of resistant variants being selected, and could also achieve synergistic antiviral effects. In this regard, a series of chemically distinct molecules were identified using in silico HTS for each binding site, derived from a drug repurposing library. Hits were shortlisted for predicted binding, their chemical properties, and compounds predicted to bind both sites removed. Screening of resultant compounds using dye release assays identified multiple hits targeting both sites, which were also validated for antiviral effects in ZIKV infectious assays. Whilst it is possible that the canonical targets for these repurposed compounds might exert indirect antiviral activity rather than acting upon $\mathrm{M}$, the chances of this occurring for the complete set were remote given their diversity (Table 3).

By far the most potent hit against M was GNF 5837, which was predicted to bind the L1 site. GNF 5837 is a potent inhibitor of Tropomyosin receptor kinases (TrK) A, B and C, high affinity receptors for nerve growth factor (NGF) that regulate neuronal survival and differentiation(58). GNF 5837 has an $\mathrm{IC}_{50}$ of $\sim 10 \mathrm{nM}$ against its cognate targets, yet only achieved an antiviral $\sim \mathrm{EC}_{50}$ at $80 \mathrm{nM}$ in $\mathrm{BHK}$ cell plaque reduction assays. Moreover, the anti-proliferative effects that would ensue from this compound interfering with NGF signalling were not evident from MTT assays. Other lumenal hits comprised the c-Src inhibitor, KB SRC 4(59) (250 nM), and GSK 2837808A(60) (40 $\mu \mathrm{M})$, an inhibitor of lactate dehydrogenase $A$ and $B(L D H A / B)$. KB SRC 4 has an in vitro Ki of $44 \mathrm{nM}$ versus C-SrC (higher against other Src-related kinases), whilst GSK 2837808A has an $\mathrm{IC}_{50}$ of 2.6 and $43 \mathrm{nM}$ against LDHA/B, respectively; the former impeded cell metabolic activity at $500 \mathrm{nM}$, whilst the latter had no effect. We therefore surmise that GSK $2837808 \mathrm{~A}$ is likely affecting ZIKV replication specifically, due to the considerable increase in effective concentration required, whereas it is conceivable that both GNF 5837 and KB SRC 4 may exert indirect, albeit potent antiviral effects. 
bioRxiv preprint doi: https://doi.org/10.1101/2021.03.11.435022; this version posted March 12, 2021. The copyright holder for this preprint (which was not certified by peer review) is the author/funder, who has granted bioRxiv a license to display the preprint in perpetuity. It is made available under aCC-BY-NC-ND 4.0 International license.

The peripheral hits tested in culture comprised Formoterol hemifumarate $(80 \mu \mathrm{M}), \mathrm{L}-732183(40 \mu \mathrm{M})$ and AA $29504(10 \mu \mathrm{M})$. Only high concentrations of Formoterol impeded metabolic activity (100 $\mu \mathrm{M})$. Formoterol is a long-acting $\beta_{2}$-adrenergic receptor agonist $\left(\mathrm{IC}_{50}\right.$ in $\mathrm{pM}$ range), used as a bronchodilator in the treatment of chronic obstructive pulmonary disease (COPD)(61). L-732 183 is a potent competitive tachykinin $\mathrm{NK}_{1}$ receptor antagonist $\left(\mathrm{IC}_{50}=2.3 \mathrm{nM}\right)$, the receptor for substance $P(62)$, whilst $A A 29504(63)$ is a positive allosteric modulator of $\mathrm{GABA}_{A}$ receptors $\left(\mathrm{IC}_{50}=9-13 \mu \mathrm{M}\right)$. Thus, we consider both Formoterol and L-732 183 to be highly unlikely to act as indirect antivirals, whereas AA 29504 requires additional investigation to ensure M-specific activity.

The compounds identified herein represent the first steps towards the design of bespoke M inhibitors through the exploration of chemical space around potent repurposed ligands; ideally, this will enable the continued emphasis on developing small molecules with superior qualities compared to rimantadine, or other prototypic viroporin inhibitors. Nevertheless, given its activity in vivo and in cell culture, there may be some value in considering the immediate clinical repurposing of rimantadine to combat severe ZIKV infection and/or trans-placental transmission during early clinical trials. The epidemic in South America and ensuing worldwide spread illustrated the speed with which ZIKV can be transmitted. ZIKV is also unique amongst Flaviviruses as it can also spread from person to person via sexual contact(64), as well as tragically infecting the unborn foetus causing microcephaly(65). It is possible that emerging ZIKV replicase-targeted drugs such as Galidesivir will not be safe to use during pregnancy due to potential teratogenic effects, although recent studies in Rhesus macaques did not indicate any issues(13). The FDA classes rimantadine as a class $\mathrm{C}$ drug during pregnancy, i.e. administered if the potential benefit might outweigh the risk. Whilst rimantadine will cross mouse placentas, eleven times the maximum recommended human dose (MRHD) is necessary to become embryotoxic. However, 3.4 and 6.8 times the MRHD did increase pup mortality up to four days postpartum, yet this still by far exceeds the dose used during influenza prophylaxis in the past (Product Information. Flumadine (rimantadine). Forest Pharmaceuticals, St. Louis, MO. 2007). No controlled studies have been undertaken during human pregnancy, but faced with the alternative of microcephaly, the risk may be worthwhile. The generic status of rimantadine also means that it could 
be deployed rapidly at minimal cost to areas of endemic ZIKV infection or during outbreaks, which overwhelmingly tend to occur in lower/middle income countries (LMIC).

In summary, this work supports the formation of ion channels by the ZIKV M protein with an essential role during virus entry in cell culture and, critically, in a preclinical model. Rimantadine might constitute an easy-to-access generic drug for the treatment and/or prophylaxis against ZIKV in LMIC. Moreover, the selection of new repurposed ligands with anti-M activity demonstrates the potential for developing novel therapies targeting this protein, which in turn may also apply to other members of the Flaviviruses. In addition, the enrichment of ligands versus both a lumenal and a peripheral binding site, combined with their potency, demonstrates the value of molecular models generated herein as templates for future drug development. The confidence in these models will be further enhanced via iterative drug development to generate a structure-activity relationship (SAR) for inhibitors targeting each site. In the longer term, structural information on M channel structures, ideally located within virion membranes, will be essential to both developing novel therapeutics, and then in turn, using these to investigate the precise roles for M channel function during ZIKV infection. 
bioRxiv preprint doi: https://doi.org/10.1101/2021.03.11.435022; this version posted March 12, 2021. The copyright holder for this preprint (which was not certified by peer review) is the author/funder, who has granted bioRxiv a license to display the preprint in perpetuity. It is made available under aCC-BY-NC-ND 4.0 International license.

\section{Materials and Methods}

Cell culture. Vero (African Green Monkey kidney) and BHK-21 (baby hamster kidney) cells were cultured in Dulbecco's modified essential cell culture media, supplemented with $10 \%$ FCS and 100 units $/ \mathrm{ml}$ penicillin and $0.1 \mathrm{mg} / \mathrm{ml}$ streptomycin, at $37^{\circ} \mathrm{C}$ in $5 \% \mathrm{CO} 2$ in a humidified culture incubator. Cells were passaged every 2-3 days using Trypsin/EDTA (SIGMA), sub-dividing cultures using ratios between 1:5 and 1:10, depending upon confluency. C6/36 cells (derived from Aedes albopictus mosquitoes) were cultured in L-15 media, supplemented with $10 \%$ TPB, $10 \%$ FCS and 100 units $/ \mathrm{ml}$ penicillin and $0.1 \mathrm{mg} / \mathrm{ml}$ streptomycin, at $28{ }^{\circ} \mathrm{C}$ with no added $\mathrm{CO}_{2}$.

Virus stocks. ZIKV/H. sapiens/Brazil/PE243/2015 (PE243) Zika virus(37) was obtained from a patient in Recife. It has been sequenced and was supplied (AK laboratory) as a frozen viral stock. This was grown once in BHK-21 cells then passaged once in C6/36 cells, titrated, and stored frozen $\left(-80^{\circ} \mathrm{C}\right)$ at $6 \times 10^{6} \mathrm{PFU} / \mathrm{mL}$. New stocks for use in cell culture were generated in house at $1.6 \times 10^{\wedge} 6$ PFU/mL in Vero cells (cell culture assays). C6/36 derived stocks were used for in vivo assays. Briefly, $\sim 6 \times 10^{6}$ Vero cells were seeded into a T75 (Corning) and left to settle over $4 \mathrm{hr}$. Cells were then washed once in PBS, prior to addition of PE243 virus in complete DMEM media +10 mM HEPES (Gibco), at a multiplicity of infection (MOI) of 0.001 PFU/cell. Infections were allowed to proceed for $1 \mathrm{hr}$ at $37^{\circ} \mathrm{C}, 5 \% \mathrm{CO} 2$, then supernatants were replaced with fresh media. Development of $\sim 60 \%$ cytopathic effect (CPE) led to harvesting and clarification of supernatants $\left(3184 \times \mathrm{g}, 20 \mathrm{~min}, 4^{\circ} \mathrm{C}\right.$, in an Eppendorf $5810 \mathrm{R}$ centrifuge). Aliquots were then titred by plaque assay (see below), snap frozen, and stored at $-80^{\circ} \mathrm{C}$.

Determination of virus titre and inhibitor assays. Plaque assays for titration (Vero) or plaque reduction (BHK21) assays were performed upon cells at $80 \%$ confluency in 12-well plates. For titration, 10 -fold serial dilutions of viral supernatants were made in $0.75 \%$ PBSA (PBS containing $0.75 \%$ bovine serum albumin) and $200 \mu \mathrm{L}$ added to wells for $1 \mathrm{hr}$ with rocking every $15 \mathrm{~min} .2 \mathrm{~mL}$ overlay media were then added (2X MEM medium (Gibco), 4 \% FCS (Gibco), 200 units/mL penicillin 
bioRxiv preprint doi: https://doi.org/10.1101/2021.03.11.435022; this version posted March 12, 2021. The copyright holder for this preprint (which was not certified by peer review) is the author/funder, who has granted bioRxiv a license to display the preprint in perpetuity. It is made available under aCC-BY-NC-ND 4.0 International license.

and $0.2 \mathrm{mg} / \mathrm{mL}$ streptomycin, mixed with viscous $1.2 \%$ Avicel (FMC Biopolymer)) and cells incubated for 5 (Vero) or $3(\mathrm{BHK} 21)$ days at $5 \% \mathrm{CO}_{2}$ and $37^{\circ} \mathrm{C}$. Supernatants were removed and cells fixed in PBS/10\% paraformaldehyde (PFA) for one $\mathrm{hr}$ at $4{ }^{\circ} \mathrm{C}$ prior to staining with $0.1 \%$ Toludine Blue (Sigma) for 30 min. Plaque reduction assays comprised duplicate wells per condition with 10 PFU added in the presence of inhibitor or DMSO solvent control (maximum of $0.1 \% \mathrm{v} / \mathrm{v}$ ).

Single cell infectious assays were conducted upon Vero cells seeded at 2000 cells per well in a 96 wells cell culture dish (Greiner Bio-one). After settling for $4 \mathrm{hr}$, cells were incubated for one hour with virus stock diluted in complete medium at an $\mathrm{MOI}$ of $1 \mathrm{PFU} /$ cell. Following infection virus containing media was removed, cells were washed with PBS and replaced with fresh cell culture media, prior to incubating at $37{ }^{\circ} \mathrm{C}$ and $5 \% \mathrm{CO} 2$ for $48 \mathrm{hr}$ in a humidified incubator. Cells were then washed three times in PBS, fixed using 4 \% PFA for 10 min at RT, and stained for ZIKV E. Briefly, cells were permeabilised using $0.1 \%$ TX-100 in PBS at RT for $10 \mathrm{~min}$, then stained using a mouse monoclonal anti-ZIKV E antibody (Aalto Bio Reagents \#AZ1176) diluted 1:500 in $10 \%$ v/v FCS in PBS overnight at $4{ }^{\circ} \mathrm{C}$. Cells were washed three times in PBS prior to adding goat anti-mouse Alexa Fluor $488 \mathrm{~nm}$ -conjugated secondary antibody, diluted 1:500 in 10\% v/v FCS in PBS at RT for $1 \mathrm{hr}$. Cells were washed another three times in PBS and left in PBS for imaging. Infectious units (FFU) were determined using an IncuCyte Zoom (Essen Bioscience) to determine numbers of fluorescently labelled cells as well as confluency, as described previously(66). The $10 \mathrm{x}$ objective was used to take four images covering each well, with positive and negative control wells allowing modification of the processing definition parameters for optimal detection.

Preclinical ZIKV model. In vivo animal models were approved by the University of Leeds local ethics review committee. Procedures were carried out in accordance with the United Kingdom Home Office regulations under the authority of the appropriate project and personal license (awarded to CSM, and CSM/DL respectively). Wild type C57BL/6j mice were bred in-house and maintained under specific pathogen-free conditions. Mice were age and sex matched in all in vivo experiments, and used between 4 and 12 weeks of age. 
bioRxiv preprint doi: https://doi.org/10.1101/2021.03.11.435022; this version posted March 12, 2021. The copyright holder for this preprint (which was not certified by peer review) is the author/funder, who has granted bioRxiv a license to display the preprint in perpetuity. It is made available under aCC-BY-NC-ND 4.0 International license.

Mice were dosed with $1.5 \mathrm{mg}$ InVivoMAb anti-mouse IFNAR-1 antibody $24 \mathrm{hr}$ prior to virus inoculation, then a sub-cutaneous dose of rimantadine hydrochloride at $20 \mathrm{mg} / \mathrm{kg}$ (or carrier control) $30 \mathrm{~min}$ prior to ZIKV infection. Mice were then anaesthetised using $0.1 \mathrm{~mL} / 10 \mathrm{~g}$ of Sedator/Ketavet via intraperitoneal (I.P.) injection, then placed on top of mosquito cages using foil to expose only the dorsal side of one hind foot. No more than 5 mosquitoes were allowed to feed on each mouse. 2000 PFU of C6/36 derived ZIKV was injected directly into the bite site using a $5 \mu \mathrm{L} 75 \mathrm{~N}$ syringe, $26 \mathrm{ga}$ (Hamilton) using small RN ga33/25mm needles (Hamilton). A second bolus of rimantadine was administered $5 \mathrm{hr}$ post-infection. Mice were observed four times throughout the 24-hr experiment, weighed once, and culled $24 \mathrm{hr}$ post-infection.

Mice were culled via a schedule 1 method. Skin from the bitten foot was dissected and placed in 0.5 $\mathrm{mL}$ RNAlater (Sigma Aldrich, USA) in $1.5 \mathrm{~mL}$ tubes. Blood was collected from the ventricles by cardiac puncture, and then centrifuged to isolate serum and stored at $-80^{\circ} \mathrm{C}$.

Mosquito rearing. Aedes aegypti (Liverpool strain) mosquitoes were reared at $28{ }^{\circ} \mathrm{C}$ with $80 \%$ humidity conditions with a $12 \mathrm{~h}$ light/dark cycle. Eggs were hatched overnight from filter papers in trays containing approximately $1.5 \mathrm{~cm}$ depth of water. Larvae were fed Go-cat cat food until pupation. Pupae were placed in water-filled containers inside BugDorm mosquito cages where they were left to emerge. A $10 \% \mathrm{w} / \mathrm{v}$ sucrose solution was fed to adult mosquitoes. Mosquitoes were ready for biting experiments from 21 days post-hatching.

RNA purification and quantification. Skin tissue was lysed in $1 \mathrm{~mL}$ Trizol (Invitrogen/Thermo) by shaking with $7 \mathrm{~mm}$ stainless steel beads at $50 \mathrm{~Hz}$ for $10 \mathrm{~min}$ on a Tissue Lyser. $200 \mu \mathrm{L}$ chloroform was added and samples mixed by inversion, prior to centrifugation in a microcentrifuge at $12000 \mathrm{x}$ $g$ for 15 min at $4{ }^{\circ} \mathrm{C}$ and removal of the top aqueous phase to a fresh tube containing an equal volume of $70 \%(\mathrm{v} / \mathrm{v}) \mathrm{EtOH}$. RNA was then extracted using a PureLink RNA Mini kit (Life Technologies) according to manufacturer's instructions. cDNA was synthesised from $1 \mu \mathrm{g}$ of RNA 
bioRxiv preprint doi: https://doi.org/10.1101/2021.03.11.435022; this version posted March 12, 2021. The copyright holder for this preprint (which was not certified by peer review) is the author/funder, who has granted bioRxiv a license to display the preprint in perpetuity. It is made available under aCC-BY-NC-ND 4.0 International license.

using the "Applied Biosystems High Capacity RNA to cDNA" kit, according to manufacturer's instructions.

cDNA was diluted 1 in 5 in RNAse free water, then introduced into a master mix comprising cDNA, primers, water and SYBRÒ green mix. A non-template control (NTC) comprising RNAse free water in place of cDNA was also included. Triplicate technical replicates were made for each biological replicate and a standard curve generated by 10 -fold serial dilution of the $10^{-2}$ PCR standard. PCR plates were run on an Applied Biosystems Quantstudio 7 flex machine. Ct value was calculated automatically using the Quantstudio software, which detects the logarithmic phase of the PCR reaction. Samples were quantified according to their position on the standard curve, which was required to have close to $100 \%$ efficiency, indicated by $R^{2} \geq 0.998$ and a slope of 3.3 . Melt curves were conducted to control for primer specificity. Analysis of qPCR data was done with Microsoft Excel by the use of the median of the technical replicates and normalizing them to the median of the technical replicates of the housekeeping genes. GraphPad Prism software was used to generate graphs and the non-parametric Mann-Whitney test was used for comparisons between two groups.

Western blotting. 6-well plates seeded with $1 \times 10^{5}$ Vero cells were infected with ZIKV at an MOI of $0.1 \mathrm{PFU} /$ cell as above, then media applied containing increasing concentrations of rimantadine or a DMSO solvent control $(0.1 \% \mathrm{v} / \mathrm{v})$. Cells were harvested at $48 \mathrm{hr}$ post infection by washing three times in $1 \mathrm{~mL}$ PBS and scraping into a $1.5 \mathrm{~mL}$ Eppendorf tube. Cells were pelleted at $10000 \times \mathrm{g}$ in a microcentrifuge, then whole cell lysates were made in $200 \mu \mathrm{L}$ Enriched Broth Culture (EBC) lysis buffer [50 mM Tris HCl, pH 8.0, $140 \mathrm{mM} \mathrm{NaCl}, 100 \mathrm{mM} \mathrm{NaF}, 200 \mu \mathrm{M} \mathrm{Na}_{3} \mathrm{VO}_{4}, 0.1 \%$ (v/v) SDS, $1 \%$ Triton X100, Roche complete ULTRA protease inhibitor cocktail]. Lysates were normalised for protein concentration using a Pierce BCA Protein Assay Kit (Thermo Fisher Scientific), then diluted with an equal volume of 2x Laemmli Buffer (100 mM Tris HCl pH 6.8, $4 \%$ (v/v) SDS, $20 \%$ (v/v) Glycerol, $10 \mathrm{mM}$ DTT, $0.025 \%$ (w/v) Bromophenol Blue). Lysates were denatured by heating for 10 $\min$ at $95{ }^{\circ} \mathrm{C}$ prior to separation on hand-cast Tris-Glycine polyacrylamide gels. Proteins were resolved by SDS-PAGE (25 $\mathrm{mM}$ Tris-Cl, $\mathrm{pH} 8.0,250 \mathrm{mM}$ Glycine, $0.1 \%$ SDS) then transferred to a polyvinylide fluoride (PVDF, Immunoblot-FL Merck Millipore) membrane, pre-activated in $100 \%$ 
$\mathrm{MeOH}$, using a Hoeffer semi-dry transfer rig, sandwiched in blotting paper soaked in transfer buffer (25 mM Tris-Cl, 250 mM Glycine, pH 8.3, $20 \%$ v/v MeOH). Transfers proceeded for 1-2 hr at 120$240 \mathrm{~mA}$ constant current, depending on the number of gels. Membranes were blocked in $5 \% \mathrm{w} / \mathrm{v}$ fat-free milk in TBS-T (Tris-buffered saline (50 mM Tris-Cl, $\mathrm{pH} 7.5,150 \mathrm{mM} \mathrm{NaCl}$ ) with $0.1 \% \mathrm{v} / \mathrm{v}$ Tween 20, Sigma-Aldrich) for $4 \mathrm{hr}$ at RT with gentle shaking, prior to incubation with primary antibodies diluted in $5 \%(\mathrm{w} / \mathrm{v}) \mathrm{BSA}$ in TBS-T at $4{ }^{\circ} \mathrm{C}$ overnight with gentle shaking (Anti-E 1:10000, mouse monoclonal, Aalto Bio Reagents \#AZ1176). Membranes were then washed three times for $10 \mathrm{~min}$ in TBS-T, prior to incubation with secondary antibody (1/10000 goat anti-mouse lgGHorseradish peroxidase (HRP) conjugate, Sigma \#A4416). Blots were visualised using ECL prime western blotting detection reagent (GE Healthcare Life Sciences) by exposure to X-ray film, with protein sizes determined by comparison with pre-stained molecular weight markers (Seeblue®) Plus2, Invitrogen).

Native PAGE. M peptide was solubilised at $37^{\circ} \mathrm{C}$ for $10 \mathrm{~min}$ in $300 \mathrm{mM}$ detergent (1,2-dihexanoylsn-glycero-3-phosphocholine (DH(6)PC), 1,2-diheptanoyl-sn-glycero-3-phosphocholine (DH(7)PC), 1-palmitoyl-2-hydroxy-sn-glycero-3-phospho-(1'-rac-glycerol) (LPPG) and 1-myristoyl-2-hydroxy-snglycero-3-phospho-(1'-rac-glycerol) (LMPG)) in Liposome Assay Buffer (10 mM HEPES, pH 7.4, 107 $\mathrm{mM} \mathrm{NaCl}$ ). Native-PAGE loading dye (150 mM Tris-Cl pH 7.0, $30 \%$ (v/v) Glycerol, $0.05 \%$ (w/v) bromophenol blue) was added to samples, which were loaded onto gradient precast gels (4-20\%) (TGX, Bio-Rad) and run using Native-PAGE running buffer (250 mM Tris-Cl, pH 8.5, $192 \mathrm{mM}$ Glycine) at 140 V for $1 \mathrm{hr}$. Gels were stained with Coomassie Brilliant Blue $(0.1 \%(\mathrm{w} / \mathrm{v})$ Coomassie Blue, $10 \%$ acetic acid, $50 \% \mathrm{MeOH}$ ). Unstained SDS-free molecular weight markers (Sigma-Aldrich) were used to estimate protein size.

Synthetic M peptide. M peptide with an N-terminal truncation (residues 18-75) was manufactured by Alta Bioscience, provided as a lyophilised powder at $>95 \%$ purity based upon HPLC. Peptides contained the sequence: 


\section{Ac - ESREYTKHLIKVENWIFRNPGFALVAVAIAWLLGSSTSQKVIYLVMILLIAPAYS}

Transmission Electron Microscopy. $5 \mu \mathrm{g}$ of M peptide was incubated in $10 \mathrm{mM}$ HEPES, $107 \mathrm{mM}$ $\mathrm{NaCl}$ and varying concentrations of $\mathrm{DH}_{(6)} \mathrm{PC}$ for 10 min at $\mathrm{RT}$. Sample was added to copper grids with a continuous amorphous carbon film, before washing with water, then stained with $1 \%$ uranyl acetate. Grids were examined using a Tecnai F20 at $120 \mathrm{kV}$ on a FEI CETA camera with a sampling of $4.18 \AA$ per pixel. Particles were manually picked and 2D class averaging were carried out using RELION 3 software(67).

Liposome dye release assay. L- $\alpha$-phosphatidic acid ( $\alpha-P A), L-\alpha-p h o s p h a t i d y l$ choline ( $\alpha-P C)$ and L- $\alpha$-phosphatidyl ethanolamine with lissamine rhodamine $b$ labelled head groups ( $\alpha-P E)$ from chicken eggs, supplied at $10 \mathrm{mg} / \mathrm{ml}$ in chloroform, were purchased from Avanti Polar Lipids. Aliquots were made using Hamilton glass syringes in glass vials, then stored at $-80{ }^{\circ} \mathrm{C}$. Lipids were combined into a glass tube on ice under non-oxygen gas (Nitrogen), as a total of $1 \mathrm{mg}$ (50 $\mu \mathrm{L}$ PA, $50 \mu \mathrm{L}$ PC \& $5 \mu \mathrm{L}$ PE). Lipids were dried initially under Nitrogen, then overnight using a vacuum dessicator at RT. Lipids were then rehydrated in carboxyfluorescein (CF)-containing buffer (50 mM CF 10 mM HEPES$\mathrm{NaOH}$ pH $7.4107 \mathrm{mM} \mathrm{NaCl}$ ) to $2 \mathrm{mg} / \mathrm{mL}$, with vigorous shaking overnight at RT). The following day, liposomes were generated via extrusion (15 passes) using an Avanti mini extruder housing a $0.4 \mu \mathrm{M}$ filter (Whatmann), at $37^{\circ} \mathrm{C}$. Resulting unilamellar liposomes were washed at least three times in liposome assay buffer (10 mM HEPES pH 7.4, $107 \mathrm{mM} \mathrm{NaCl}$ ) to remove unincorporated CF, pelleting liposomes at $100000 \times g$ for 15 min at RT using a MLS-50 rotor in a Beckman Coulter TLX ultracentrifuge. Final pellets were resuspended in assay buffer $(500 \mu \mathrm{L})$ and concentration determined by comparing rhodamine absorbance $\left(O D_{570 \mathrm{~nm}}\right)$ in pre-extrusion (diluted 1:20) and final samples:

Liposome concentration $(\mathrm{mM})=\{2.75 \mathrm{mM}$ (average lipid molarity) $/($ OD570 pre $\times 20)\} \times$ OD570 post 
bioRxiv preprint doi: https://doi.org/10.1101/2021.03.11.435022; this version posted March 12, 2021. The copyright holder for this preprint (which was not certified by peer review) is the author/funder, who has granted bioRxiv a license to display the preprint in perpetuity. It is made available under aCC-BY-NC-ND 4.0 International license.

Dye release assays were conducted using up to $800 \mathrm{nM}$ peptide (480 $\mathrm{nM}$ standard) in DMSO (maximum of $5 \% \mathrm{v} / \mathrm{v}$ DMSO per well), with $50 \mu \mathrm{M}$ liposomes in a total reaction volume of $100 \mu \mathrm{L}$. Inhibitors were pre-incubated with peptide for $5 \mathrm{~min}$ in flat-bottomed, black 96-well plates (Greiner Bio One) at RT, prior to the rapid addition of chilled liposome suspensions in assay buffer. CF release compared to solvent controls and liposomes alone was measured over 30 min at $37^{\circ} \mathrm{C}$ with initial mixing, using a FLUOstar Galaxy Optima plate-reader (BMG Labtech, $\lambda_{\mathrm{ex}} 485 \mathrm{~nm} / \lambda_{\mathrm{em}} 520 \mathrm{~nm}$. Gain adjustment at $90 \%$ total fluorescence was set using a pre-measured sample containing $0.5 \% \mathrm{v} / \mathrm{v}$ Triton X-100 to lyse all liposomes present. End-point values from three technical repeats were calculated for each averaged biological repeat and significance between the latter determined using multiple paired student T-tests. Assays assessing $\mathrm{pH}$ dependence utilised assay buffers at stated $\mathrm{pH}$, with endpoint supernatants re-buffered using $2.5 \mu \mathrm{L} 1 \mathrm{M}$ Tris- $\mathrm{Cl}[\mathrm{pH} 7.5]$ prior to clarifying by ultracentrifugation as above and determining fluorescence.

In silico analysis of M protein. Alignment of Flavivirus $M$ sequences was performed using Clustal Omega (https://www.ebi.ac.uk/Tools/msa/clustalo/), with outputs visualised using BOXSHADE 3.21 (https://embnet.vital-it.ch/software/BOX form.html). M protein tertiary structures were taken from PDB: 5IRE. Online servers used to determine probability of trans-membrane regions comprised TMHMM v2.0 (http://www.cbs.dtu.dk/services/TMHMM/), TOPCONS (https://topcons.cbr.su.se/), Phobius (https://phobius.sbc.su.se/), SPLIT v4.0 (http://splitbioinf.pmfst.hr/split/4/) and MEMSATSVM (https://bio.tools/memsat-svm). Amino acid properties were determined using EMBOSS Pepinfo (https://www.ebi.ac.uk/Tools/segstats/emboss pepinfo/).

Coarse-grained Molecular Dynamics simulations. Coarse-grained (CG) Molecular Dynamic simulations of monomeric and dimeric M proteins were performed using Martini v2.2 force field(68) and GROMACS(69). The cryo-EM structure of ZIKV M protein structure (PDB: 5IRE)(25) was converted to a coarse-grained resolution using the "martinize" script. An elastic network model was used in the monomer and dimer simulations to maintain the secondary structure, yet not the tertiary structure. However, an elastic network was used during dimerisation simulations when restraining 
both secondary and tertiary structure. The cryo-EM structure was used to simulate the two TMD model, whereas "Modeller" (70) was used to generate the second model, straightening the linker region between the two TMDs into a longer TMD. Ten repeat simulations of $3 \mu$ s each were run for each system.

A POPC bilayer was built using INSANE (INSert membrANE) CG tool(71). Systems were solvated with CG water particles and ions were added to neutralise the system to a final concentration of 150 $\mathrm{mM} \mathrm{NaCl}$. Prior to simulation, systems were energy minimised using the steepest descent algorithm for 500 steps in GROMACS and equilibrated for 10 ns with the protein backbone restrained. The temperature was set at $323 \mathrm{~K}$ and controlled by V-rescale thermostat (coupling constant of 1.0)(72). Pressure was controlled by Parrinello-Rahman barostat (coupling constant of 1.0 and a reference pressure of 1 bar)(73). Integration step was 20 fs.

Atomistic Molecular Dynamics Simulations. The all-atom hexameric and heptameric M protein oligomers were first energy minimised prior to conversion into CG using the Martini 2.2 forcefield and as above inserted into the bilayer system using INSANE. The systems were then equilibrated in CG restraining the protein. The systems were then converted back into atomistic resolution using the Martini backward tool(74). Simulations were then energy minimised, equilibrated for $20 \mathrm{~ns}$ with the protein $\mathrm{C} \alpha$ atoms restrained and run using the CHARMM36 force field(75). Three repeat simulations were run for $200 \mathrm{~ns}$ for each system. Temperature and pressure were controlled using the v-rescale thermostat(72) and Parrinello-Rahman barostat(73) respectively. Bond lengths were kept constant using the LINCS algorithm(76). The time-step was 2 fs and the temperature set to 323 $\mathrm{K}$.

Design of Hexameric and Heptameric M channel structures. A python script was used to calculate the co-ordinates of each monomer within the oligomeric structure, a radii of $1.3 \mathrm{~nm}$ was used for hexamer: 
$\mathrm{n}=6$ \# Number of sides; $\mathrm{x}=0$ \# Origin on $\mathrm{x}$ axis; $\mathrm{y}=0$ \# Origin on $\mathrm{y}$ axis: $r=1.3$ \# Radius of Circle polygon is in for $i$ in range $(0, n)$ : pos $x=x+\left(r\right.$ * math.cos $\left(2{ }^{*}\right.$ math. $\left.\left.p i^{*} i / n\right)\right)$; posy $=y+\left(r^{*}\right.$ math.sin $\left(2{ }^{*}\right.$ math.pi * $\left.\left.\mathrm{i} / \mathrm{n}\right)\right)$ print ("\% 2d : \%2.4f : \%2.4f" \% (i, posx, posy))

\section{In silico docking and virtual HTS.}

Maestro (Schrödinger) was used for assessing ligand interactions with the compact hexameric $M$ channel structure. This was minimised in a lipid membrane environment using an Optimised Potentials for Liquid Simulations (OPLS) force field and used for docking of unbiased compound analogues. The Maestro SiteMap function was used to assess the druggability score for three potential lumenal binding sites (L1-3), and another on the membrane-exposed periphery was identified manually.

For unbiased screening, a library of 1280 FDA-approved molecules (TOCRIS Screen, Biotechne. https://www.ebi.ac.uk/Tools/segstats/emboss pepinfo/) underwent the LigPrep function using Maestro (Schrödinger) software. The in-built SiteMap function was then used on the M Protein structure to generate a Glide grid for the docking of Rimantadine in the lumenal site (under aqueous conditions) using extra precise (XP) Glide setting. This was followed by docking in the same site mimicking membrane conditions. Rimantadine was then docked into the peripheral site under both aqueous and membrane conditions to generate 32 poses in each of the four scenarios. The prepared Tocris library was also docked into the two sites on the M protein structure using the four scenarios and Glide settings established using Rimantadine (lumenal-aqueous, lumenal-membrane, peripheral-aqueous, and peripheral-membrane). Duplicate poses were removed, and a final shortlist of 50 molecules was generated at each for in vitro testing. 
bioRxiv preprint doi: https://doi.org/10.1101/2021.0311.435022 t this version posted March 12,2021 . The copyright holder for this preprint (which was not certified by peer review) is the author/funder, who has granted bioRxiv a license to display the preprint in perpetuity. It is made available under aCC-BY-NC-ND 4.0 International license.

\section{Acknowledgments}

Schematics in figures $1 \mathrm{e}, 3 \mathrm{~d}, 4 \mathrm{a}$ and $\mathrm{S} 2 \mathrm{~b}$ were generated using Biorender software (https://biorender.com) with a paid subscription. Simulations were undertaken on ARC3 and ARC4, part of the High Performance Computing facilities at the University of Leeds. Work was supported by Institute PhD Scholarships from the Leeds Institute of Medical Research, University of Leeds, (EB and DF: awarded to SG, CM, AK, and RF), Medical Research Council grant G0700124 (S.G.), and Medical Research Council grants (MC_UU_12014/8 and MR/N017552/1) (A.K.). 
bioRxiv preprint doi: https://doi.org/10.1101/2021.03.11.435022; this version posted March 12, 2021. The copyright holder for this preprint (which was not certified by peer review) is the author/funder, who has granted bioRxiv a license to display the preprint in perpetuity. It is made available under aCC-BY-NC-ND 4.0 International license.

\section{Figure Legends}

Figure 1. In silico and in vitro characterisation of $M$. A. Alignment of M sequences from ZIKV and other Flaviviruses using Clustal Omega and visualised using Boxshade 3.21. Black signifies sequence identity, grey similarity, white differences. B. M sequence amino acid characteristics visualised using EMBOSS Pepinfo. C. M sequence showing helical regions and peptide truncation (in vitro synthesis and MD simulations). D. Native PAGE of M peptide $(5 \mu \mathrm{g})$ reconstituted in $\mathrm{DH}_{(6)} \mathrm{PC}$ (300 mM). E. Titration of DMSO-reconstituted M peptide in endpoint liposome CF release assay. Graph represents a single biological repeat representative of at least three others, comprising triplicate technical repeats at each concentration. Error bars show standard deviation. F. Modified endpoint CF assay undertaken with altered external buffer $\mathrm{pH}$ as indicated. CF content of re-buffered clarified assay supernatants were detected as a single endpoint measurement. Data comprise three biological repeats for each condition, error bars show normalised standard error, ${ }^{*} p \leq 0.05$, Student T-test. G. Effect of rimantadine $(1 \mu \mathrm{M})$ upon $\mathrm{M}$ activity. Results are from three biological repeats normalised to $100 \%$ activity for solvent control. Error bars show adjusted \% error. ${ }^{*} p \leq 0.05$, Student T-test.

Figure 2. Transmission electron microscopy (TEM) of $M$ peptides in $D H_{(6)} P C$ micelles. A. Visualisation of $\mathrm{M}$ peptide with increasing concentrations of detergent, stained with uranyl acetate. Fields are representative of multiple images with $~ 9000$ particles collected in total across all conditions. Insets show zoomed images of particles with accumulation of stain within central cavity, consistent with channel formation. B. Top panel - examples of particles visualised at $150 \mathrm{mM}$ illustrating heterogeneity. 9907 particles from 150 mM samples were resolved into 2D class averages with 25 iterations (bottom panel) yet rotational symmetry could not be determined.

Figure 3. Rimantadine blockade of ZIKV infection. A. Vero cells were infected at an MOI of 0.1 pfu/cell with increasing rimantadine concentrations in 96 well plates. Infectious units were quantified $48 \mathrm{hr}$ post-infection using an IncuCyte Zoom to count ZIKV infected cells stained with antibody to 
ZIKV E and an Alexafluor $488 \mathrm{~nm}$ secondary antibody. Counts were averaged over four image panels per well and results are from three biological replicates performed in triplicate. Error bars represent standard error of the mean between experiments. ${ }^{*} p \leq 0.01,{ }^{* *} p \leq 0.001$, paired student $\mathrm{T}$ test relative to solvent control. B. Representative anti-E western blot of $n=3$ biological repeats of 6 well plate experiments run in parallel to fluorescence-based assays. Infections and timings as for A. C. Example representative fluorescence images from IncuCyte analysis shown in A. D. Plaque reduction assay using BHK21 cells infected with $10 \mathrm{pfu} /$ well in the presence of $80 \mu \mathrm{M}$ rimantadine during different stages of infection shown by schematic. $\mathrm{N}=2$ biological replicates. Error bars represent standard error of the mean between experiments, ${ }^{*} p \leq 0.01$, paired student T-test relative to solvent control.

Figure 4. Predicted membrane topology for $M$ protomers. A. Image of an energy minimised $M$ protomer taken from PDB: 5IRE within a simulated hydrated lipid membrane system (see methods). B. Comparison of straightened, single TM M protomer (left) with the original cryo-EM conformation (right). C. Single TM protomer inserted into a bilayer and subjected to CG simulations for $3 \mu$, running from start (top) to finished (middle) pose. RMSD over time (bottom) showed a high degree of movement and flexibility exhibited by this conformation, as the protein appears to attempt moving back towards a two TM structure. D. Two TM structure simulated in a model bilayer as for C. RMSD remained comparatively stable over time and the region adjoining the inter-helical loop induced snorkelling of lipid envelope.

Figure 5. Influence of the $N$-terminal helix upon dimeric interactions between $M$ protomers. A. Structure of $E$ and $M$ dimers within the ZIKV virion (PDB: 5IRE) showing close interactions between M N-terminal helix and E. B. Formation of "virion"-like "type 1" dimeric interactions during coursegrained simulations of two separated protomers in membranes. Helices are arranged in an antiparallel formation as per PDB: 5IRE. Residues making close contacts are shown graphically (right), with protomer 1 in red, two in black. C. As for B, but for "type 3" aligned dimers where 
bioRxiv preprint doi: https://doi.org/10.1101/2021.03.11.435022; this version posted March 12, 2021. The copyright holder for this preprint (which was not certified by peer review) is the author/funder, who has granted bioRxiv a license to display the preprint in perpetuity. It is made available under aCC-BY-NC-ND 4.0 International license.

protomers are aligned and increased contacts occur between protomers (right). D. Representation of time taken for dimers to form $(\mu \mathrm{s})$ and the final conformation of dimer interactions, where $\mathrm{N}$ terminal helix is either free to move (left) or is rigidified (right).

Figure 6. Simulated hexameric M channel complex in a compact formation, lined by helix 3. A. Assembly of protomers into compact hexamer model using Maestro. Left - ribbon diagram illustrating position of His28 (red); middle - space filling model showing individual protomer (gold); right - space filling model showing pore diameter using HOLE. B. Overlay of compact helix 3 model from one of the 200 ns simulations. C. Cutaway of channel viewed from the side showing pore-lining residues predicted for the compact hexamer from the side and the top.

Figure 7. Opening of protonated compact hexamers increases compared to neutral $\mathrm{pH}$. A. Neutral (left) versus protonated (right) compact hexameric complexes over a 200 ns simulation overlaying start (white) and endpoint (black) conformations. B. HOLE profile for lumenal aperture showing differences between starting configuration (blue line) and final structures over three separate $100 \mathrm{~ns}$ atomistic simulations (green, red, black). Left - neutral $\mathrm{pH}$, right - protonated. C. Zoomed images of lumenal constrictions arising upon closure of neutral (left) or protonated (right) channel complexes, with colour-coded HOLE profiles for the aqueous pore. D. Simulation of M complexes where the Nterminal helix was removed, leading to rapid $(<50 \mathrm{~ns})$ dissociation of the channel complex.

Figure 8. Predicted inhibitor binding-sites within the lumen and periphery of compact hexameric $M$ complexes. A. Compact $\mathrm{M}$ channel complex models were assessed using the SiteMap package within Maestro for cavities corresponding to high druggability scores. Three sites were found within the lumen (L1-L3), with $L 1$ retaining the most favourable score. In addition, a site upon the membrane-exposed channel periphery was evident upon visual inspection (P1), yet would not be expected to score as highly in SiteMap due to solvent exposure of compounds in the absence of the surrounding membrane during simulated docking. This is reminiscent of similar sites within HCV p7 
and IAV M2. Notably, both L1 and P1 reside within close proximity to the predicted gating region near Leu64. B. Consistent with SiteMap scoring, the L1 domain was the best fit for rimantadine docking within the lumen. C. Rimantadine derivatives showed overlapping binding modes with rimantadine at the same L1 binding site, but with opposite orientations such that the hydrophobic adamantyl cage was predicted to project into the lumen. D. Compounds from a peripheral site upon the HCV p7 channel complex were tested using CF release assays to ascertain the potential relevance of the $\mathrm{P} 1$ site; these have a more planar structure compared with rimantadine. Reassuringly, two such compounds (JK3/34 and JK3/42) were effective at inhibiting $\mathrm{M}$ channel activity, distinct from the HCV series lead (JK3/32), which had no effect.

Figure 9. Inhibition of ZIKV replication by in silico enriched drugs from a repurposing library. A. Compounds selected to bind the L1 and P1 sites in silico were tested for effects in ZIKV culture, using a BHK21 cell plaque reduction assay. Compounds were used at maximal concentrations shown not to evoke cellular toxicity by MTT assays (see fig SX). Experiments are biological triplicates with error bars representing the standard error of the mean. ${ }^{* *} p \leq 0.01,{ }^{*} p \leq 0.05$, Student T-test. Example biological repeat with triplicate technical repeats for the two top compounds targeting the L1 and P1 sites, GNF 5837 (L1) and AA 29504 (P1). C. Predicted binding pose of GNF 5837 at L1 site generated using Glide (Maestro, Schrodinger) with interactions shown in D. E and $\mathbf{F}$ showing same for AA 29504.

Figure 10. Anti-ZIKV activity in preclinical models. A. Schematic of preclinical experiments involving transient IFNAR blockade, augmentation of ZIKV infection through mosquito bites and treatment with rimantadine. B. RT-qPCR for ZIKV E relative to 18S RNA from skin tissue at injection site derived from one of two representative experiments. C. Infectious titre of serum derived from rimantadine treated or control mice, determined by plaque assay in BHK21 cells. ${ }^{* * *} p \leq 0.0001$, Student T-test.

\section{Tables}


Table 1. Top 50 lumenally targeted compounds from the TOCRIS screen library, ranked by glide score.

Table 2. Top 50 peripherally targeted compounds from the TOCRIS screen library, ranked by glide score.

Table 3. Properties of hits taken forward into ZIKV cell culture screens, including effects versus canonical targets.

\section{Supplementary Figures}

Figure S1. HPLC and mass spectrometry analysis of synthetic M peptides supplied by Alta Biosciences.

Figure S2. Controls for off-target effects of rimantadine during infectious ZIKV culture. A. Viability of Vero cells measured using MTT assay after $48 \mathrm{hr}$ incubation with rimantadine or DMSO control for $48 \mathrm{hr}$. Graph summarises a single representative biological repeat with three technical repeats. Error bars represent one standard deviation. B. Lack of effect of rimantadine upon uptake of fluorescently labelled EGF by endocytosis. Top - experimental schematic. Bottom - endocytic uptake of fluorescently labelled (FITC) EGF in Vero cells pre-treated with 5 to $80 \mu \mathrm{M}$ rimantadine. Uptake was measured using flow cytometry and quantified in 25000 cells per condition and expressed as median FITC, displayed as a \% of maximum fluorescent EGF uptake at $0 \mu \mathrm{M}$ rimantadine. Bafilomycin A1 was used at $1 \mu \mathrm{M}$ as a positive control for blocking endocytic uptake.

Figure S3. Prediction of $\mathrm{M}$ protein trans-membrane regions, topology and hydrophobic profiles generated in different online server packages. 
Figure S4. Additional less frequent M dimer conformations adopted during simulations. Top and side views are shown for each pose as well as plots for residue contacts for chain 1 (red) and chain 2 (black).

Figure S5. A. Simulation system box for M protein hexamers in hydrated DOPC bilayers. B. Overlay of compact (white) vs radial (black) hexamer conformation.

Figure S6. A. Starting conformations for compact radial hexamer with lumenal helix 3, showing high similarity to non-protonated forms. B. Structures of protonated channels at 100 ns including HOLE profile of channel lumen. C. HOLE radius of starting (blue) and 100 ns (yellow, pink, red) conformations and zoomed image of channel constriction at Leu64.

Figure S7. Lack of inhibitory activity for other adamantane derivatives versus $M$ in CF release assays.

Figure S8. Screening data for lumenally and peripherally targeted $\mathrm{M}$ binding compounds, enriched using in silico HTS. The top 50 compounds based upon predicted binding scores and drug-like properties derived from the TOCRIS repurposing library were tested versus $\mathrm{M}$ at $1 \mu \mathrm{M}$ using CF release assays. Results show the average of three biological repeats, with error bars representing the standard error of the mean.

Figure S9. Effects of screening hits upon cell metabolic activity measured by MTT assay in Vero cells. Compound titrations were performed according to remain below cytotoxic doses described in the literature. Results show the average of three biological repeats, with error bars representing the standard error of the mean. 
Figure S10. Predicted binding poses and residue interactions for peripherally targeted hit compounds.

Figure S11. Predicted binding poses and residue interactions for lumenally targeted hit compounds.

Annexe. Additional modelling solutions for oligomers with properties deemed less favourable compared to the compact hexameric complex lined by helix 3 . This includes standard and protonated $\left(\right.$ His $\left.28^{++}\right)$simulations for radial arrangements of the complex, complexes lined by helix 2 as well as heptameric assemblages across all conditions.

Each model and simulation is depicted as overall structure (A), cut-away and top-down images of complexes highlighting lumenal regions (neutral only, B), representative endpoint conformation following simulations $(\mathbf{C})$ and HOLE profiles describing channel lumenal apertures for start (blue) and final (red, green, black) conformations (D). 
bioRxiv preprint doi: https://doi.org/10.1101/2021.03.11.435022; this version posted March 12,2021 . The copyright holder for this preprint (which was not certified by peer review) is the author/funder, who has granted bioRxiv a license to display the preprint in perpetuity. It is made available under aCC-BY-NC-ND 4.0 International license.

\section{References}

1. G. W. Dick, Zika virus. II. Pathogenicity and physical properties. Trans R Soc Trop M ed Hyg 46, 521534 (1952).

2. G. W. Dick, S. F. Kitchen, A. J. Haddow, Zika virus. I. Isolations and serological specificity. Trans R Soc Trop Med Hyg 46, 509-520 (1952).

3. D. I. Simpson, Zika Virus Infection in M an. Trans R Soc Trop M ed Hyg 58, 335-338 (1964).

4. H. M. Lazear, M. S. Diamond, Zika Virus: New Clinical Syndromes and Its Emergence in the Western Hemisphere. J Virol 90, 4864-4875 (2016).

5. Z. Gong, X. Xu, G. Z. Han, The Diversification of Zika Virus: Are There Two Distinct Lineages? Genome Biol Evol 9, 2940-2945 (2017).

6. S. A. Rasmussen, D. J. Jamieson, Teratogen update: Zika virus and pregnancy. Birth Defects Res $\mathbf{1 1 2}$ 1139-1149 (2020).

7. S. A. Rasmussen, D. J. Jamieson, M. A. Honein, L. R. Petersen, Zika Virus and Birth Defects--Reviewing the Evidence for Causality. N Engl J M ed 374, 1981-1987 (2016).

8. S. A. Rasmussen, D. M. Meaney-Delman, L. R. Petersen, D. J. Jamieson, Studying the effects of emerging infections on the fetus: Experience with West Nile and Zika viruses. Birth Defects Res 109, 363-371 (2017).

9. A. T. Peterson, J. Osorio, H. Qiao, L. E. Escobar, Zika Virus, Elevation, and Transmission Risk. PLoS Curr 8. (2016).

10. G. A. Poland et al., Development of vaccines against Zika virus. Lancet Infect Dis 18, e211-e219 (2018).

11. N. M umtaz et al., Cell-line dependent antiviral activity of sofosbuvir against Zika virus. Antiviral Res 146, 161-163 (2017).

12. S. Masmejan, D. Baud, D. Musso, A. Panchaud, Zika virus, vaccines, and antiviral strategies. Expert Rev Anti Infect Ther 16, 471-483 (2018).

13. S. Y. Lim et al., A direct-acting antiviral drug abrogates viremia in Zika virus-infected rhesus macaques. Sci Transl Med 12 (2020).

14. M. A. Garcia-Blanco, S. G. Vasudevan, S. S. Bradrick, C. Nicchitta, Flavivirus RNA transactions from viral entry to genome replication. Antiviral Res 134, 244-249 (2016).

15. D. Ray et al., West Nile virus 5'-cap structure is formed by sequential guanine N-7 and ribose 2'-0 methylations by nonstructural protein 5. J Virol 80, 8362-8370 (2006).

16. R. Assenberg et al., Crystal structure of a novel conformational state of the flavivirus NS3 protein: implications for polyprotein processing and viral replication. J Virol 83, 12895-12906 (2009).

17. V. M. Prasad et al., Structure of the immature Zika virus at 9 A resolution. Nat Struct M ol Biol 24, 184186 (2017).

18. T. Y. Tan et al., Capsid protein structure in Zika virus reveals the flavivirus assembly process. Nat Commun 11, 895 (2020).

19. I. M. Yu et al., Structure of the immature dengue virus at low $\mathrm{pH}$ primes proteolytic maturation. Science 319, 1834-1837 (2008).

20. K. Stadler, S. L. Allison, J. Schalich, F. X. Heinz, Proteolytic activation of tick-borne encephalitis virus by furin. J Virol 71, 8475-8481 (1997).

21. M. Sevvana et al., Refinement and Analysis of the Mature Zika Virus Cryo-EM Structure at $3.1 \mathrm{~A}$ Resolution. Structure 26, 1169-1177 e1163 (2018).

22. K. A. Dowd, S. M ukherjee, R. J. Kuhn, T. C. Pierson, Combined effects of the structural heterogeneity and dynamics of flaviviruses on antibody recognition. J Virol 88, 11726-11737 (2014).

23. J. Junjhon et al., Differential modulation of prM cleavage, extracellular particle distribution, and virus infectivity by conserved residues at nonfurin consensus positions of the dengue virus pr-M junction. Journal of virology 82, 10776-10791 (2008).

24. I. M. Yu et al., Association of the pr peptides with dengue virus at acidic $\mathrm{pH}$ blocks membrane fusion. Journal of virology 83, 12101-12107 (2009).

25. D. Sirohi et al., The 3.8 A resolution cryo-EM structure of Zika virus. Science 352, 467-470 (2016).

26. X. Zhang et al., Structure of acidic $\mathrm{pH}$ dengue virus showing the fusogenic glycoprotein trimers. J Virol 89, 743-750 (2015). 
bioRxiv preprint doi: https://doi.org/10.1101/2021.03.11.435022; this version posted March 12,2021 . The copyright holder for this preprint (which was not certified by peer review) is the author/funder, who has granted bioRxiv a license to display the preprint in perpetuity. It is made available under aCC-BY-NC-ND 4.0 International license.

27. S. Bressanelli et al., Structure of a flavivirus envelope glycoprotein in its low-pH-induced membrane fusion conformation. Embo J 23, 728-738 (2004).

28. K. Stiasny, S. Bressanelli, J. Lepault, F. A. Rey, F. X. Heinz, Characterization of a membrane-associated trimeric low-pH-induced Form of the class II viral fusion protein $\mathrm{E}$ from tick-borne encephalitis virus and its crystallization. J Virol 78, 3178-3183 (2004).

29. Y. M odis, S. Ogata, D. Clements, S. C. Harrison, Variable surface epitopes in the crystal structure of dengue virus type 3 envelope glycoprotein. J Virol 79, 1223-1231 (2005).

30. V. Nayak et al., Crystal structure of dengue virus type 1 envelope protein in the postfusion conformation and its implications for membrane fusion. J Virol 83, 4338-4344 (2009).

31. Y. Zhang et al., Conformational changes of the flavivirus E glycoprotein. Structure 12, 1607-1618 (2004).

32. A. Premkumar, C. R. Horan, P. W. Gage, Dengue virus M protein C-terminal peptide (DVM-C) forms ion channels. The Journal of membrane biology 204, 33-38 (2005).

33. S. S. Wong, M. Chebib, G. Haqshenas, B. Loveland, E. J. Gowans, Dengue virus PrM /M proteins fail to show pH-dependent ion channel activity in Xenopus oocytes. Virology 412 83-90 (2011).

34. J. L. Nieva, V. Madan, L. Carrasco, Viroporins: structure and biological functions. Nature reviews. Microbiology 10, 563-574 (2012).

35. J. Royle, S. J. Dobson, M. Muller, A. Macdonald, Emerging Roles of Viroporins Encoded by DNA Viruses: Novel Targets for Antivirals? Viruses 7, 5375-5387 (2015).

36. C. Scott, S. Griffin, Viroporins: structure, function and potential as antiviral targets. J Gen Virol 96, 2000-2027 (2015).

37. C. L. Donald et al., Full Genome Sequence and sfRNA Interferon Antagonist Activity of Zika Virus from Recife, Brazil. PLoS Negl Trop Dis 10, e0005048 (2016).

38. B. OuYang et al., Unusual architecture of the $\mathrm{p} 7$ channel from hepatitis C virus. Nature 498, 521-525 (2013).

39. R. M. Pielak, J. J. Chou, Solution NM R structure of the V27A drug resistant mutant of influenza A M 2 channel. Biochemical and biophysical research communications 401, 58-63 (2010).

40. R. M. Pielak, J. R. Schnell, J. J. Chou, M echanism of drug inhibition and drug resistance of influenza A M 2 channel. Proc Natl Acad Sci U S A 106, 7379-7384 (2009).

41. J. R. Schnell, J. J. Chou, Structure and mechanism of the M2 proton channel of influenza A virus. Nature 451, 591-595 (2008).

42. T. L. Foster et al., Resistance mutations define specific antiviral effects for inhibitors of the hepatitis C virus $p 7$ ion channel. Hepatology 54, 79-90 (2011).

43. C. StGelais et al., Determinants of hepatitis $C$ virus $p 7$ ion channel function and drug sensitivity identified in vitro. Journal of virology $\mathbf{8 3}, 7970-7981$ (2009).

44. L. F. W etherill et al., High-risk human papillomavirus E5 oncoprotein displays channel-forming activity sensitive to small-molecule inhibitors. Journal of virology 86, 5341-5351 (2012).

45. S. D. Carter et al., Direct visualization of the small hydrophobic protein of human respiratory syncytial virus reveals the structural basis for membrane permeability. FEBS Lett 584, 2786-2790 (2010).

46. T. L. Foster et al., Structure-guided design affirms inhibitors of hepatitis C virus $p 7$ as a viable class of antivirals targeting virion release. Hepatology 59, 408-422 (2014).

47. S. Griffin et al., Genotype-dependent sensitivity of hepatitis $C$ virus to inhibitors of the $\mathrm{p} 7$ ion channel. Hepatology 48, 1779-1790 (2008).

48. C. Scott et al., Site-directed M 2 proton channel inhibitors enable synergistic combination therapy for rimantadine-resistant pandemic influenza. PLoS Pathog 16, e1008716 (2020).

49. J. Shaw et al., Rationally derived inhibitors of hepatitis C virus (HCV) p7 channel activity reveal prospect for bimodal antiviral therapy. Elife 9, (2020).

50. C. StGelais et al., Inhibition of hepatitis C virus p7 membrane channels in a liposome-based assay system. Antiviral research 76, 48-58 (2007).

51. S. Walter et al., Ion-channel function and cross-species determinants in viral assembly of nonprimate hepacivirus p7. J Virol, (2016).

52. E. Atkins et al., The stability of secreted, acid-labile H77/JFH-1 hepatitis C virus (HCV) particles is altered by patient isolate genotype la p7 sequences. Virology 448, 117-124 (2014). 
bioRxiv preprint doi: https://doi.org/10.1101/2021.03.11.435022; this version posted March 12,2021 . The copyright holder for this preprint (which was not certified by peer review) is the author/funder, who has granted bioRxiv a license to display the preprint in perpetuity. It is made available under aCC-BY-NC-ND 4.0 International license.

53. R. J. Kuhn et al., Structure of dengue virus: implications for flavivirus organization, maturation, and fusion. Cell 108, 717-725 (2002).

54. S. Mukhopadhyay, B. S. Kim, P. R. Chipman, M. G. Rossmann, R. J. Kuhn, Structure of West Nile virus. Science 302, 248 (2003).

55. M. Pingen et al., Host Inflammatory Response to M osquito Bites Enhances the Severity of Arbovirus Infection. Immunity 44, 1455-1469 (2016).

56. S. A. Wharton, R. B. Belshe, J. J. Skehel, A. J. Hay, Role of virion M2 protein in influenza virus uncoating: specific reduction in the rate of membrane fusion between virus and liposomes by amantadine. J Gen Virol 75( Pt 4), 945-948 (1994).

57. W. C. Koff, J. L. Elm, Jr., S. B. Halstead, Inhibition of dengue virus replication by amantadine hydrochloride. Antimicrob Agents Chemother 18, 125-129 (1980).

58. P. Albaugh et al., Discovery of GNF-5837, a Selective TRK Inhibitor with Efficacy in Rodent Cancer Tumor Models. ACS M ed Chem Lett 3, 140-145 (2012).

59. K. R. Brandvold, M. E. Steffey, C. C. Fox, M. B. Soellner, Development of a highly selective c-Src kinase inhibitor. ACS Chem Biol 7, 1393-1398 (2012).

60. J. Billiard et al., Quinoline 3-sulfonamides inhibit lactate dehydrogenase A and reverse aerobic glycolysis in cancer cells. Cancer M etab 1,19 (2013).

61. W. E. Berger, J. A. Nadel, Efficacy and safety of formoterol for the treatment of chronic obstructive pulmonary disease. Respir M ed $\mathbf{1 0 2}$ 173-188 (2008).

62. L. Quartara, C. A. Maggi, The tachykinin NK1 receptor. Part I: ligands and mechanisms of cellular activation. Neuropeptides 31, 537-563 (1997).

63. I. Vardya et al., Positive modulation of delta-subunit containing GABA(A) receptors in mouse neurons. Neuropharmacology $\mathbf{6 3}, 469-479$ (2012).

64. E. D'Ortenzio et al., Evidence of Sexual Transmission of Zika Virus. N Engl J Med 374, 2195-2198 (2016).

65. A. York, Getting to the base of Zika virus and microcephaly. Nat Rev M icrobiol 19, 2 (2021).

66. H. Stewart et al., A novel method for the measurement of hepatitis $\mathrm{C}$ virus infectious titres using the IncuCyte ZOOM and its application to antiviral screening. J Virol M ethods 218, 59-65 (2015).

67. J. Zivanov et al., New tools for automated high-resolution cryo-EM structure determination in RELION-3. Elife 7, (2018).

68. D. H. de Jong et al., Improved Parameters for the M artini Coarse-Grained Protein Force Field. J Chem Theory Comput 9, 687-697 (2013).

69. D. Van Der Spoel et al., GROM ACS: fast, flexible, and free. J Comput Chem 26, 1701-1718 (2005).

70. A. Fiser, A. Sali, Modeller: generation and refinement of homology-based protein structure models. M ethods Enzymol 374, 461-491 (2003).

71. T. A. Wassenaar, H. I. Ingolfsson, R. A. Bockmann, D. P. Tieleman, S. J. Marrink, Computational Lipidomics with insane: A Versatile Tool for Generating Custom Membranes for Molecular Simulations. J Chem Theory Comput 11 2144-2155 (2015).

72. G. Bussi, D. Donadio, M. Parrinello, Canonical sampling through velocity rescaling. J Chem Phys 126 , 014101 (2007).

73. M. Parrinello, A. Rahman, Polymorphic transitions in single crystals: A new molecular dynamics method. Journal of Applied Physics 52 (1981).

74. T. A. Wassenaar, K. Pluhackova, R. A. Bockmann, S. J. Marrink, D. P. Tieleman, Going Backward: A Flexible Geometric Approach to Reverse Transformation from Coarse Grained to Atomistic Models. J Chem Theory Comput 10,676-690 (2014).

75. J. Huang, A. D. MacKerell, Jr., CHARM M 36 all-atom additive protein force field: validation based on comparison to NMR data. J Comput Chem 34, 2135-2145 (2013).

76. B. Hess, H. Bekker, H. J. Berendsen, J. G. E. M. Fraaije, LINCS: A linear constraint solver for molecular simulations. J Comput Chem 18, 1463-1472 (1998). 
bioRxiv preprint doi: https://doi.org/10.1101/2021.03.11.435022; this version posted March 12, 2021. The copyright holder for this preprint (which was not certified by peer review) is the author/funder, who has granted bioRxiv a license to display the preprint in perpetuity. It is made available under aCC-BY-NC-ND 4.0 International license. 
Table 1. Lumenally targeted compounds

\begin{tabular}{|c|c|c|c|}
\hline "Rank" & Compound Name & Tocris ID & Glide gscore \\
\hline 1 & FR 139317 & 1210 & -10.227 \\
\hline 2 & ZCL 278 & 4794 & -9.294 \\
\hline 3 & Elinogrel & 5316 & -8.829 \\
\hline 4 & Taxol & 1097 & -8.711 \\
\hline 5 & UK 356618 & 4187 & -8.401 \\
\hline 7 & TC-1 15 & 4527 & -8.216 \\
\hline 8 & AS 2034178 & 5035 & -8.032 \\
\hline 9 & CP 775146 & 4190 & -7.963 \\
\hline 10 & GW 6471 & 4618 & -9.092 \\
\hline 11 & Pravastatin sodium salt & 2318 & -7.825 \\
\hline 12 & Fluvastatin sodium & 3309 & -7.717 \\
\hline 13 & TC NTR1 17 & 5087 & -7.683 \\
\hline$\overline{14}$ & VER 155008 & 3803 & -7.686 \\
\hline 15 & AMG PERK 44 & 5517 & -7.618 \\
\hline 16 & Glibenclamide & 0911 & -7.537 \\
\hline 17 & Argatroban & 1637 & -7.454 \\
\hline 18 & KB SRC 4 & 4660 & -7.444 \\
\hline 19 & GBR 12909 dihydrochloride & 0421 & -7.965 \\
\hline 20 & $( \pm)-N B I 74330$ & 4528 & -7.366 \\
\hline 21 & CU CPT $4 a$ & 4883 & -7.331 \\
\hline 22 & A 887826 & 4249 & $\begin{array}{ll}-7.315 \\
\end{array}$ \\
\hline 23 & SR 2640 hydrochloride & 1804 & -7.296 \\
\hline 24 & NSC 74859 & 4655 & -7.258 \\
\hline 25 & RWJ 67657 & 2999 & -7.217 \\
\hline 26 & Lu AA 47070 & 4783 & -7.659 \\
\hline 27 & Edaglitazone & 4784 & -7.176 \\
\hline 29 & GSK 1562590 hydrochloride & 5110 & -7.11 \\
\hline 30 & Flurizan & 4495 & -7.098 \\
\hline
\end{tabular}




\begin{tabular}{|c|c|c|c|}
\hline 31 & GW 9508 & 2649 & -7.096 \\
\hline 32 & GSK 269962 & 4009 & -7.051 \\
\hline 33 & AC 5216 & 5281 & -6.986 \\
\hline 34 & DBZ & 4489 & -6.973 \\
\hline 35 & PF 04418948 & 4818 & -6.957 \\
\hline 36 & GSK 2837808A & 5189 & -6.942 \\
\hline 37 & Sal 003 & 3657 & -6.935 \\
\hline 38 & PD 173212 & 3552 & -7.029 \\
\hline 39 & NTRC 824 & 5438 & -9.012 \\
\hline 40 & ONO AE3 208 & 3565 & -6.889 \\
\hline 41 & RS 17053 hydrochloride & 0985 & -6.88 \\
\hline 42 & Pitavastatin calcium & 4942 & -6.864 \\
\hline 43 & $L-161,982$ & 2514 & -6.858 \\
\hline 44 & AMN 082 dihydrochloride & 2385 & -6.871 \\
\hline 45 & TC-N 1752 & 4435 & -6.815 \\
\hline 46 & PF 431396 & 4278 & -6.799 \\
\hline 47 & GNF 5837 & 4559 & -6.754 \\
\hline 48 & KS 176 & 4169 & -6.731 \\
\hline 49 & Sarpogrelate hydrochloride & 3739 & -6.769 \\
\hline 50 & GKA 50 & 5133 & -6.689 \\
\hline $\mathrm{N} 1$ & Mifepristone & 1479 & 0.286 \\
\hline
\end{tabular}

Table 2. Peripherally targeted compounds

\begin{tabular}{|l|l|l|l|}
\hline "Rank" & Compound & Cat No & Glide gscore \\
\hline 1 & RWJ 21757 & 2719 & -6.475 \\
\hline 2 & Ferrostatin 1 & 5180 & -6.309 \\
\hline
\end{tabular}




\begin{tabular}{|c|c|c|c|}
\hline 3 & AA 29504 & 3972 & -6.31 \\
\hline 4 & L-732,138 & 0868 & -6.167 \\
\hline 5 & API-2 & 2151 & -6.158 \\
\hline 6 & 5-BDBD & 3579 & -6.13 \\
\hline 7 & LY 225910 & 1018 & -6.082 \\
\hline 8 & Formoterol hemifumarate & 1448 & -6.065 \\
\hline 9 & TC-S 7006 & 5240 & -5.979 \\
\hline 10 & TCS 2210 & 3877 & -6.005 \\
\hline 11 & Sumatriptan succinate & 3586 & -5.952 \\
\hline 12 & MRS 3777 hemioxalate & 2403 & -6.964 \\
\hline 13 & Thiamet G & 4390 & -6.079 \\
\hline 14 & Abacavir hemisulfate & 4148 & -5.894 \\
\hline 15 & DDR1-IN-1 & 5077 & -5.99 \\
\hline 16 & Fexofenadine hydrochloride & 2429 & -5.859 \\
\hline 17 & 6-Chloromelatonin & 0443 & -5.844 \\
\hline 18 & GSK 0660 & 3433 & -5.864 \\
\hline 19 & PCA 4248 & 0571 & -5.783 \\
\hline 20 & Axtinib & 4350 & -5.765 \\
\hline 21 & DSR 6434 & 4809 & -5.971 \\
\hline 22 & Necrostatin-1 & 2324 & -5.756 \\
\hline 23 & Trifluorothymidine & 4460 & -5.838 \\
\hline
\end{tabular}




\begin{tabular}{|c|c|c|c|}
\hline 24 & Cilndipine & 2629 & -5.729 \\
\hline 25 & \begin{tabular}{|ll} 
Efondipine & hydrochloride \\
monoethanolate &
\end{tabular} & 3733 & -5.693 \\
\hline 26 & ITE & 1803 & -5.69 \\
\hline 27 & L-165,041 & 1856 & -5.689 \\
\hline 28 & EB 47 & 4140 & -6.033 \\
\hline 29 & GSK 2830371 & 5140 & -5.657 \\
\hline 30 & AZD 1480 & 5617 & -5.738 \\
\hline 32 & Amlodipine besylate & 2571 & -5.638 \\
\hline 33 & Melatonin & 3550 & -5.628 \\
\hline 34 & Fludarabine & 3495 & -5.626 \\
\hline 35 & PF 06447475 & 5716 & -5.609 \\
\hline 36 & SU 6668 & 3335 & -5.608 \\
\hline 37 & AZD 5438 & 3968 & -5.836 \\
\hline 38 & SU 11274 & 4101 & -6.145 \\
\hline 39 & FPL 64176 & 1403 & -5.543 \\
\hline 40 & Sunitinib malate & 3768 & -5.543 \\
\hline 41 & YK 4-279 & 4067 & -5.535 \\
\hline 42 & Ralfinamide mesylate & 4029 & -5.678 \\
\hline 43 & ML 298 hydrochloride & 4895 & -5.504 \\
\hline 44 & $\mathrm{FH} 1$ & 5254 & -5.485 \\
\hline 45 & PLX 647 dihydrochloride & 5102 & -6.23 \\
\hline
\end{tabular}


bioRxiv preprint doi: https://doi org/10.1101/2021.03.11.435022; this version posted March 12, 2021. The copyright holder for this preprint (which was not certified by peer review) is the author/funder, who has granted bioRxiv a license to display the preprint in perpetuity. It is made available under aCC-BY-NC-ND 4.0 International license.

\begin{tabular}{|l|l|l|l|}
\hline 46 & GPi 688 & 3967 & -5.438 \\
\hline 47 & CP 94253 hydrochloride & 1317 & -5.441 \\
\hline 48 & CGP 57380 & 2731 & -5.44 \\
\hline 49 & BW 723C86 hydrochloride & 1059 & -5.433 \\
\hline 50 & LY 364947 & 2718 & -5.84 \\
\hline & & & \\
\hline
\end{tabular}


Table 3. Properties of hits tested in ZIKV culture

\begin{tabular}{|c|c|c|c|}
\hline Drug & $M$ binding site $\left(E C / I C_{50}\right)$ & $\begin{array}{ll}\text { Canonical } & \text { Target } \\
\left(\mathrm{Ki} / \mathrm{EC} / \mathrm{IC}_{50}\right) & \end{array}$ & MTT effect? \\
\hline Rimantadine & Lumen $(80 \mu \mathrm{M})$ & IAV M2 (variable) & No \\
\hline GNF 5837 & Lumen ( 80 nM) & $\begin{array}{l}\text { Tropomyosin receptor } \\
\text { kinases (TrK) A, B and C (10 } \\
n M)\end{array}$ & No \\
\hline KB SRC 4 & Lumen ( 250 nM) & $c-S r c(K i=44 n M)$ & Yes, $500 \mathrm{nM}$ \\
\hline GSK 2837808A & Lumen $(\sim 40 \mu \mathrm{M})$ & $\begin{array}{l}\text { Lactate dehydrogenase } A \\
\text { and } B(L D H A / B), 2.6 / 43 \mathrm{nM}\end{array}$ & No \\
\hline Formoterol & Periphery ( $80 \mu \mathrm{M})$ & $\begin{array}{l}\beta_{2} \text {-adrenergic receptor } \\
\text { agonist (pM range) }\end{array}$ & Yes, $100 \mu \mathrm{M}$ \\
\hline L-732, 183 & Periphery $(\sim 40 \mu \mathrm{M})$ & $\begin{array}{l}\text { Tachykinin } \quad \mathrm{NK}_{1} \text { receptor } \\
\text { antagonist }\left(\mathrm{IC}_{50}=2.3 \mathrm{nM}\right)\end{array}$ & No \\
\hline AA 29504 & Periphery $(\sim 10 \mu \mathrm{M})$ & $\begin{array}{l}\mathrm{GABA}_{A} \text { receptor } \quad \text { agonist } \\
\left(\mathrm{IC}_{50}=9-13 \mu \mathrm{M}\right)\end{array}$ & $\begin{array}{l}\text { Marginal, } \quad 20 \\
\mu \mathrm{M}\end{array}$ \\
\hline
\end{tabular}


bioRxiv preprint doi: https://doi org/10.1101/2021.03 11.435022; this version posted March 12,2021 . The copyright holder for this preprint (which was not certified by peer review) is the author/funder, who has granted bioRxiv a license to display the preprint in perpetuity. It is made available under aCC-BY-NC-ND 4.0 International license.

A

Figure 1

ZIKV AVTLPSHSTRKLOTRSOTWLESREYTKHLIKVENWTFRNPGFALVAVAIAWLLGSSTSOKVIYLVMILLIAPAYS DENV-2 SVALVPHVGMGLETRTETWMSSEGAWKHA ORIETWILRHP GFTIMAAILAYTIGTTHF ORALIF ILL TAVAPSMT

DENV - 4 SVALTPHSGMGLETRAETWMSSEGAWKHA ORVESWILRNPGFALLAGFMAYMIGOTG I QRTVFFVLMMLVAPSYG

WNV SLTVQTHGESTLANKKGAWLDSTKATRYLVKTESWILRNPGYALVAAVIGWMLGSNTM QRVVFAILLLLVAPAYS

YFV AIDLPTHENHGLKTROEKWMTGRMGERQLQKIERWFVRNPFFAVTALTIAYLVGSNMTQRVVIALLVLAVGPAYS

B

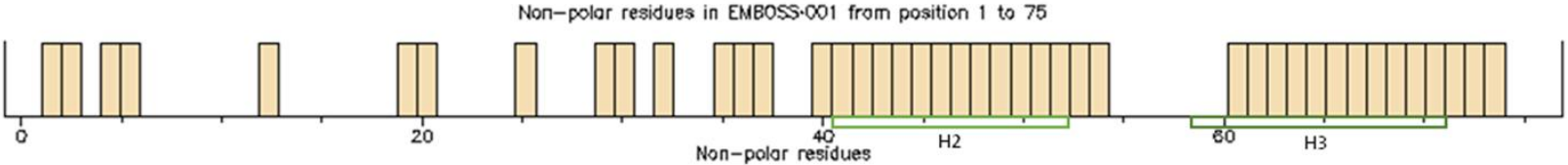

Polar residues in EMBOSS.001 from position 1 to 75

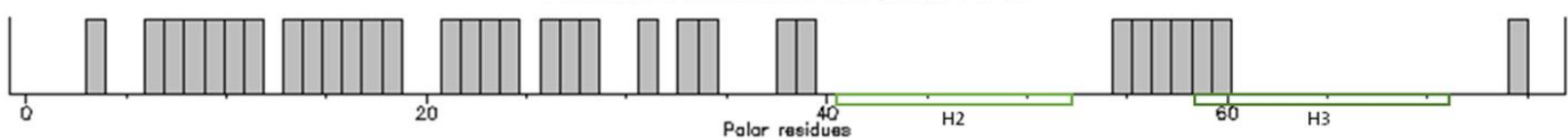

Charged residues in EMBOSS.001 from position 1 to 75

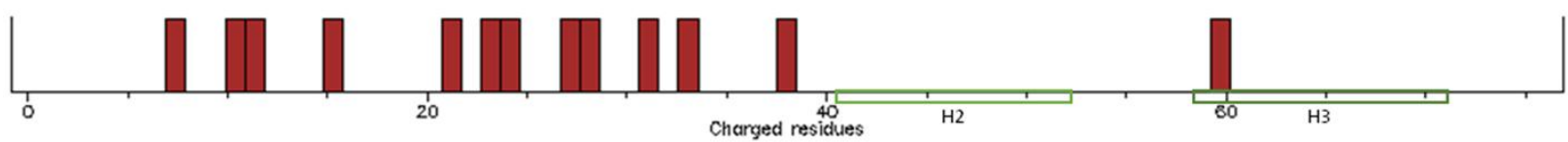

Positive residues in EMBOSS.001 from position 1 to 75

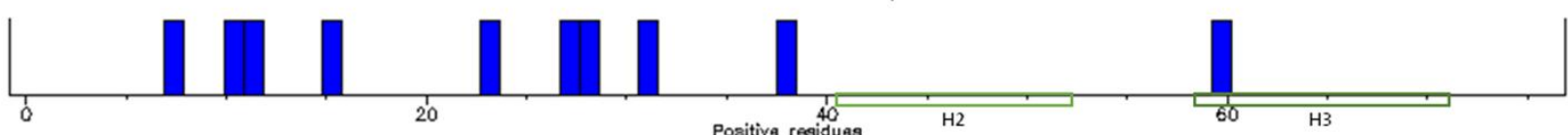

C

Peptide/M D truncation

AVTLPSHSTRKLQTRSQ $\downarrow_{\text {TWLESREYTKHLIKVENWIFRNPGFALVAVAIAWLLGSST SQKVIYLVMILLIAPAYS }}$

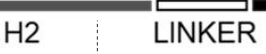

60
$\mathrm{H} 3$

70
10

20

$\mathrm{H} 1$

30

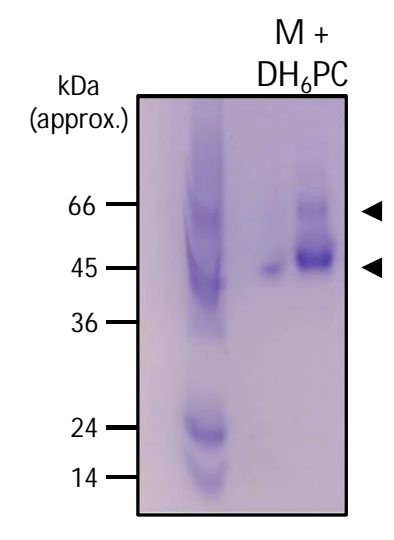

E

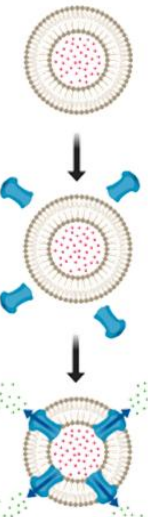

D

F

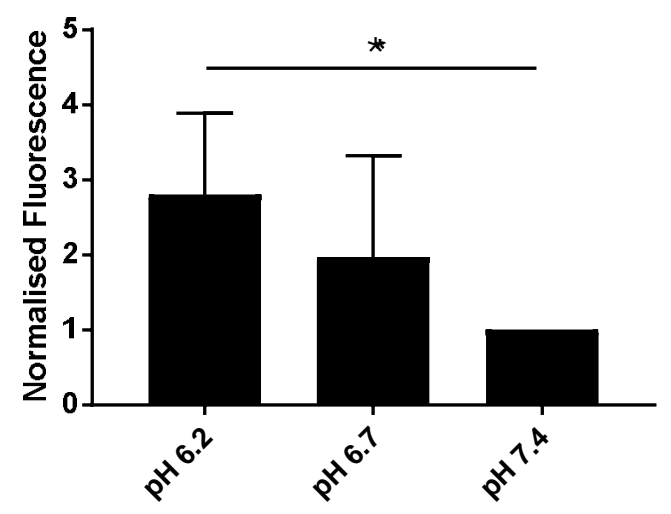

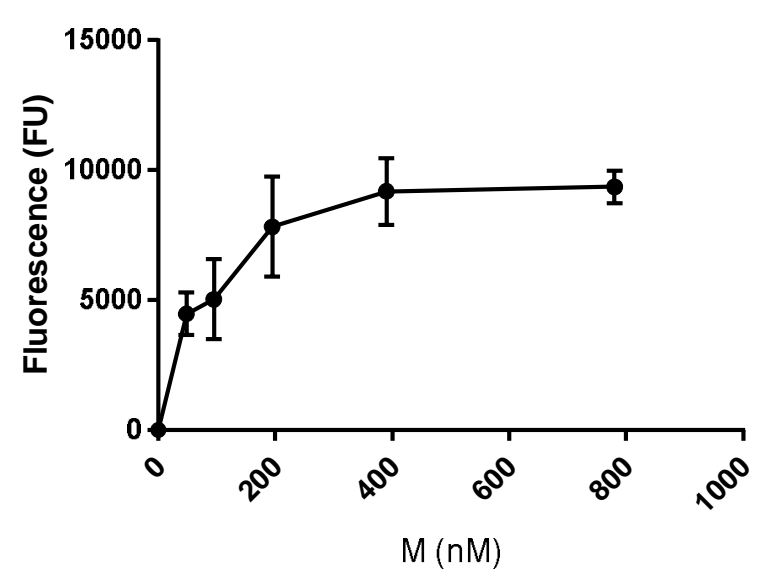

G

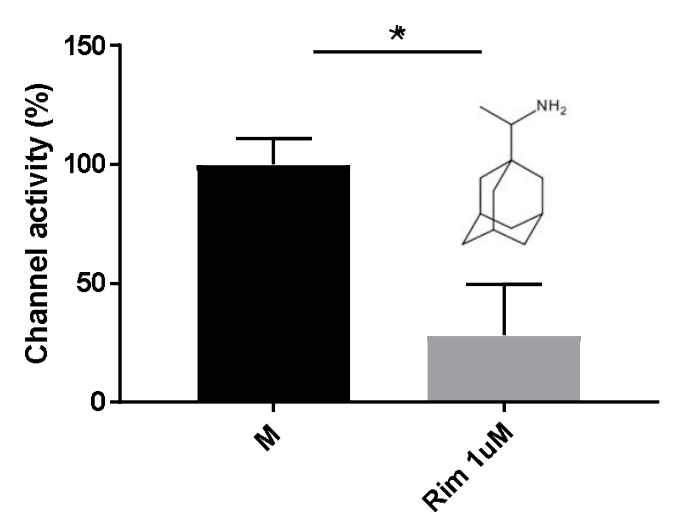


bioRxiv preprint doi: $\mathrm{https}$ //doi. org/10.1101/2021.03.11.435022; this version posted March 12 2021. The copyright holder for this preprint (which was not certified by peer review) is the author/funder, who has granted bioRxiv a license to display the preprint in perpetuity. It is made available under aCC-BY-NC-ND 4.0 International license.

A

Figure 2

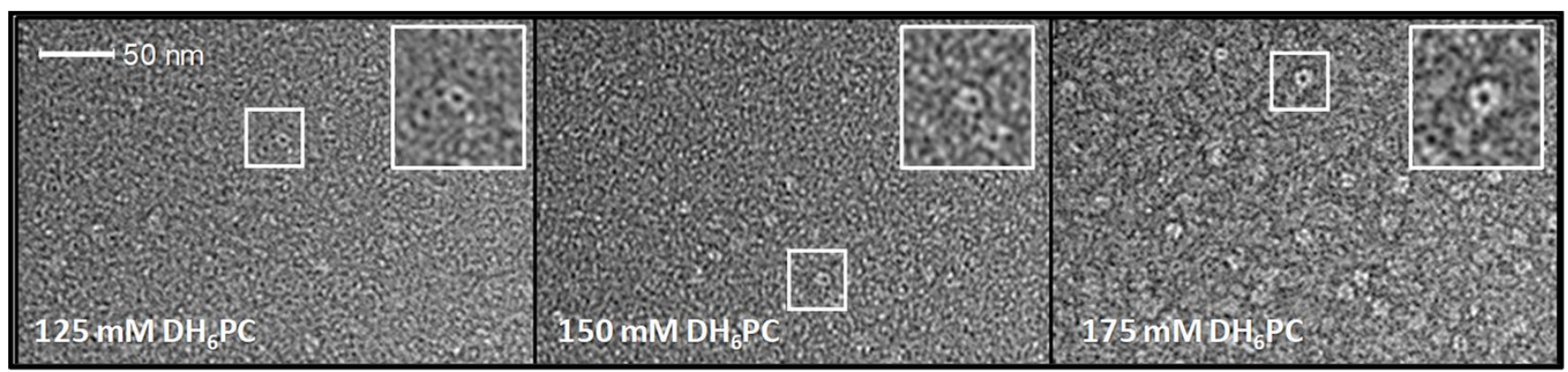

B
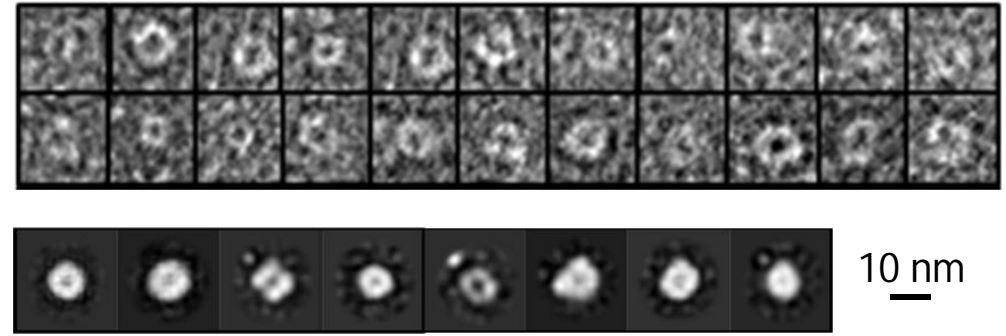
Figure 3

A

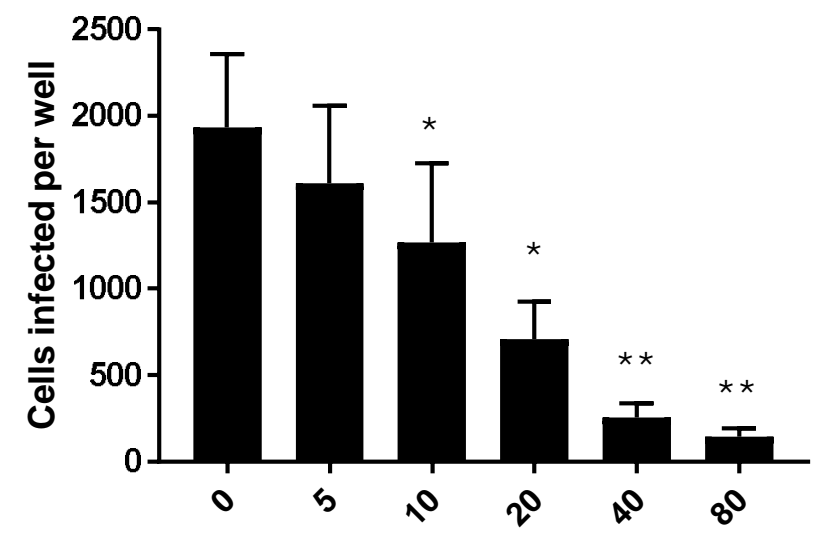

Rimantadine $/ \mu \mathrm{M}$

B

Rimantadine

$(\mu \mathrm{M}) \quad 0 \quad 5 \quad 10 \quad 20 \quad 40 \quad 80 \quad \mathrm{kDa}$

ZIKV E

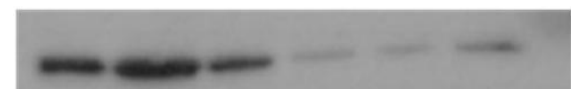

GAPDH

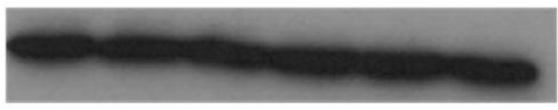

50

37
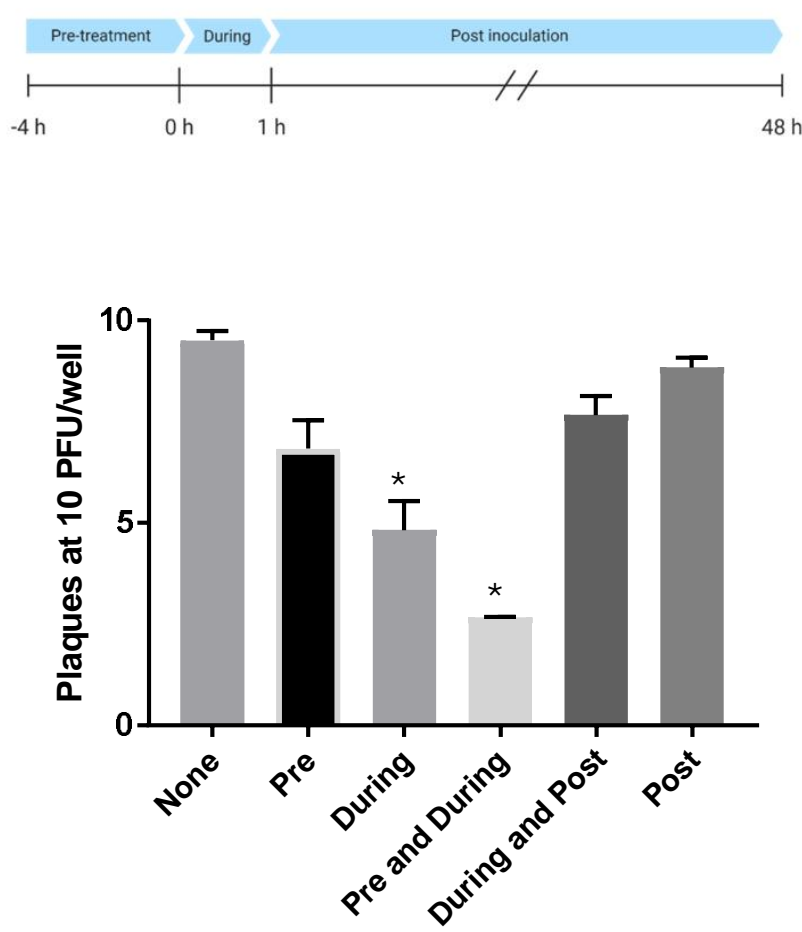
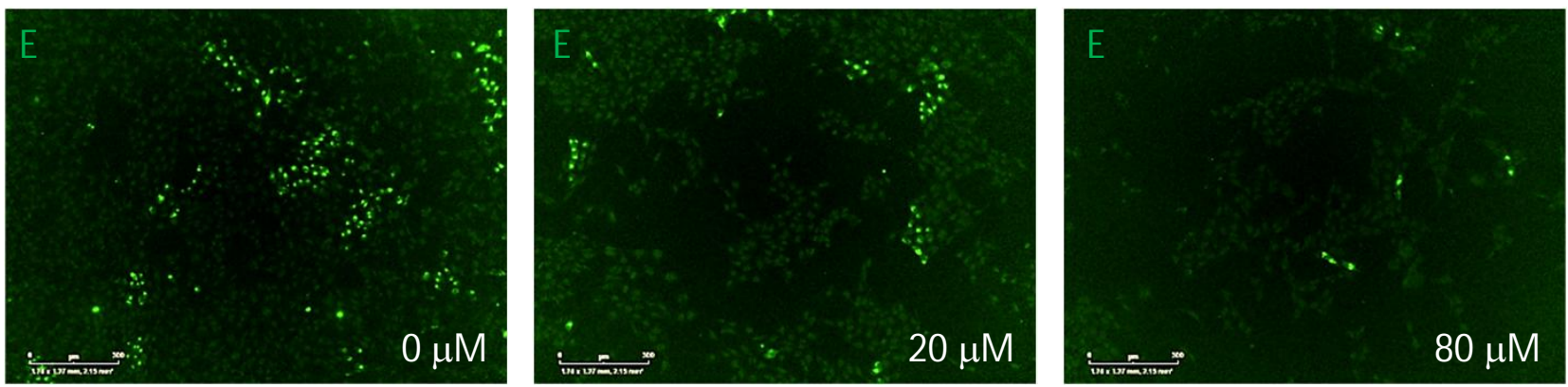
bioRxiv preprint doi: https://doi org/10.1101/2021.03.11.435022; this version posted March 12 2021. The copyright holder for this preprint (which was not certified by peer review) is the author/funder, who has granted bioRxiv a license to display the preprint in perpetuity. It is made available under aCC-BY-NC-ND 4.0 International license.

A

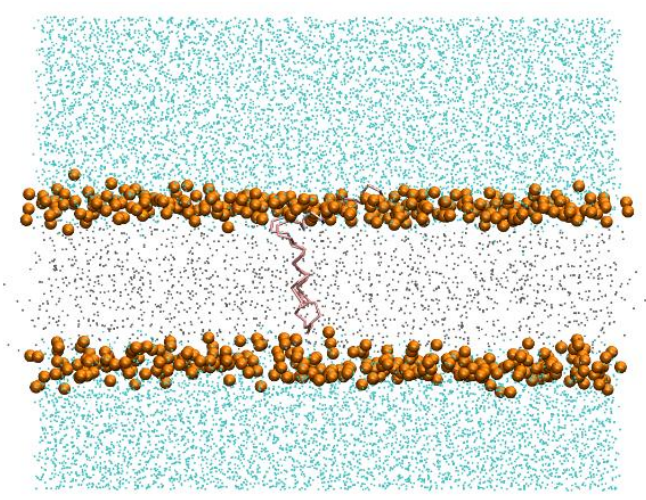

C
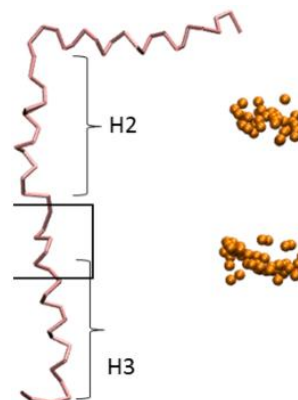

Start
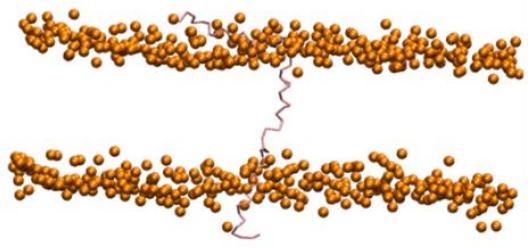

- $3 \mu \mathrm{s}$
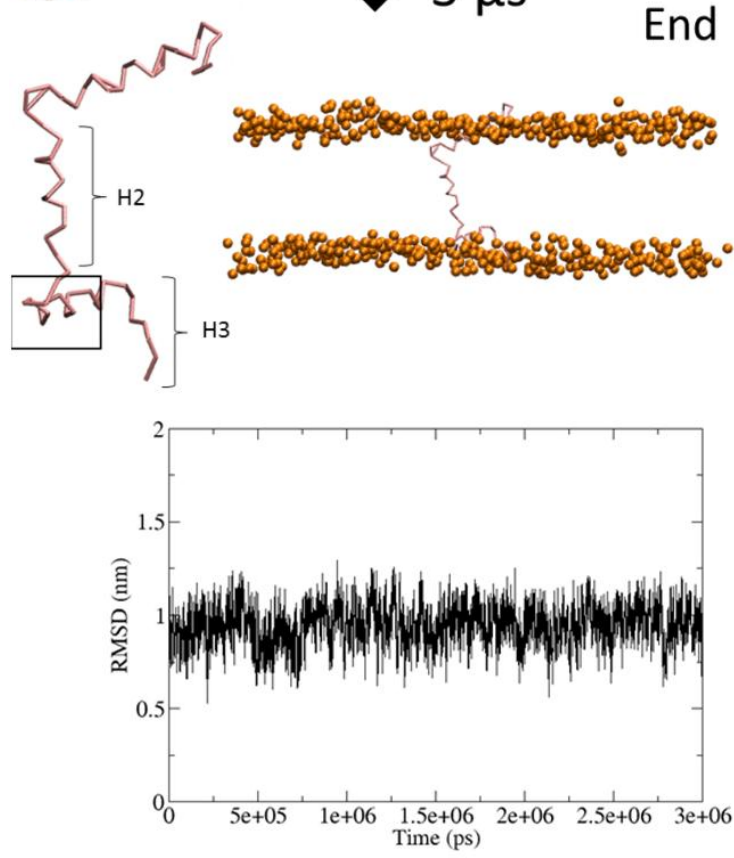

B

Figure 4

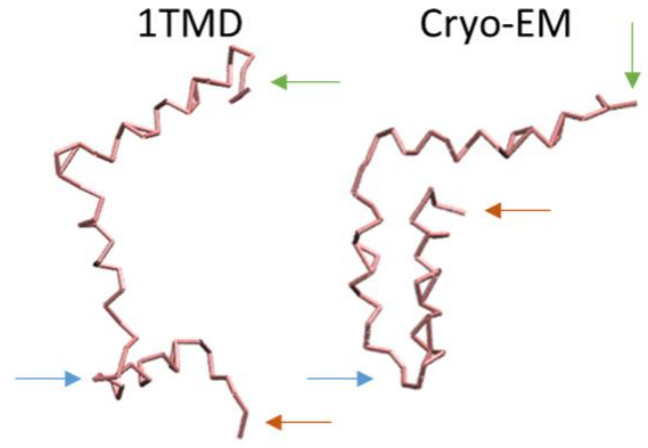

D

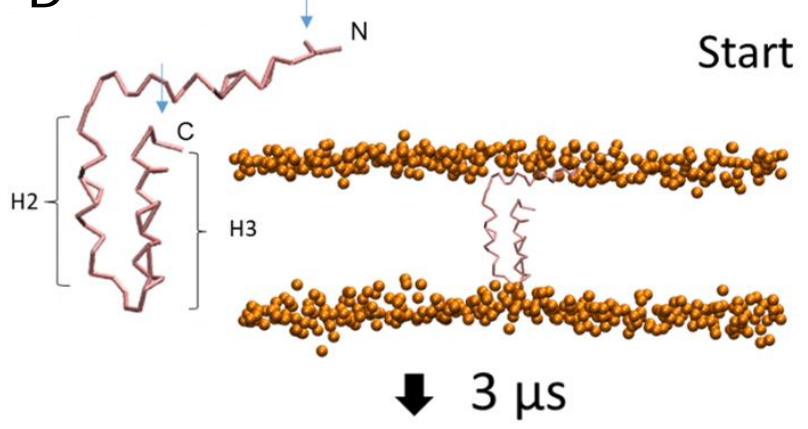

End
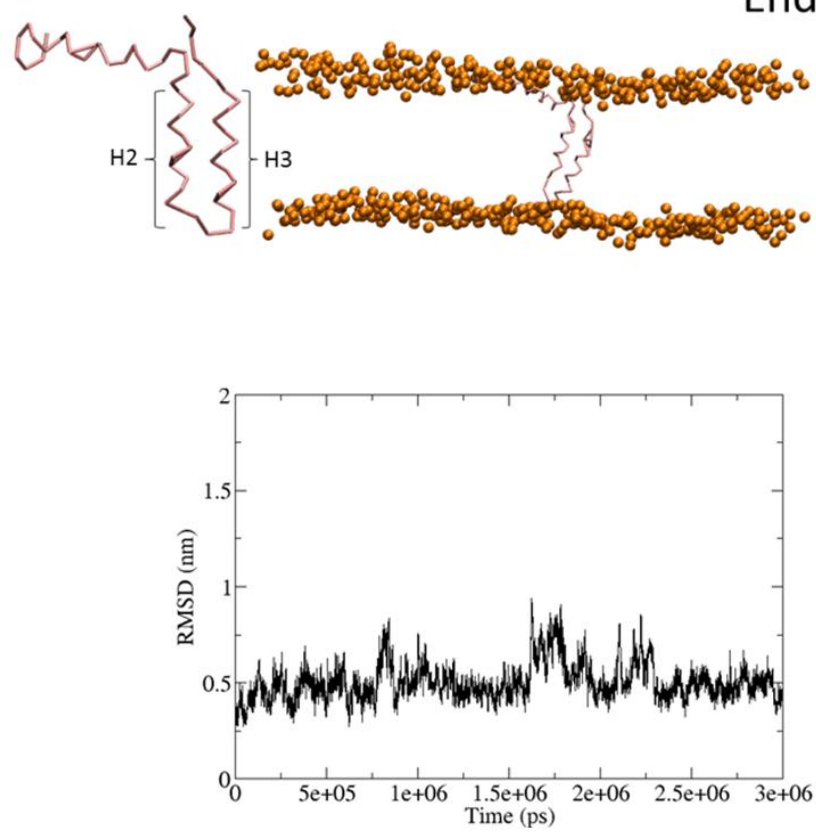
Figure 5

A

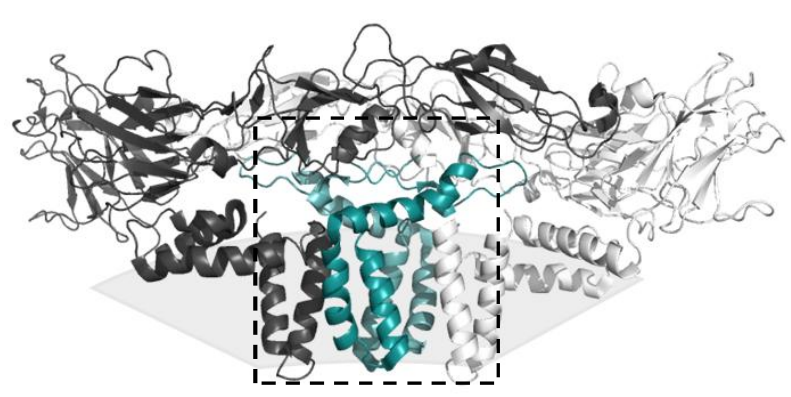

B

Class I
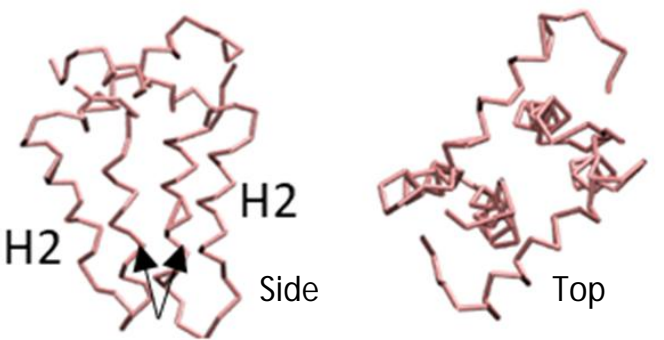

C

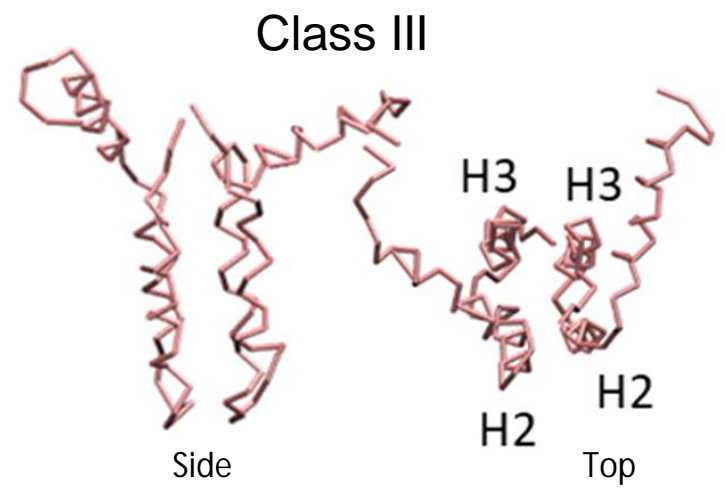

D

$\mathrm{N}$-terminus: free-moving

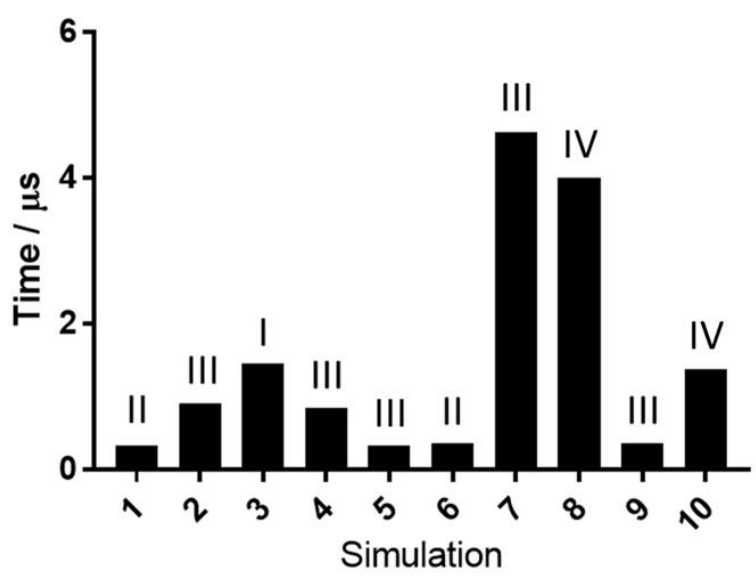

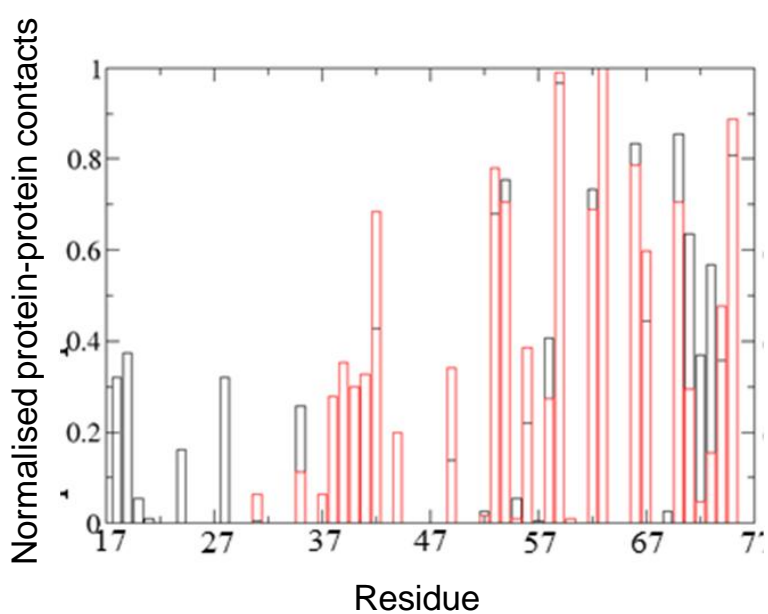

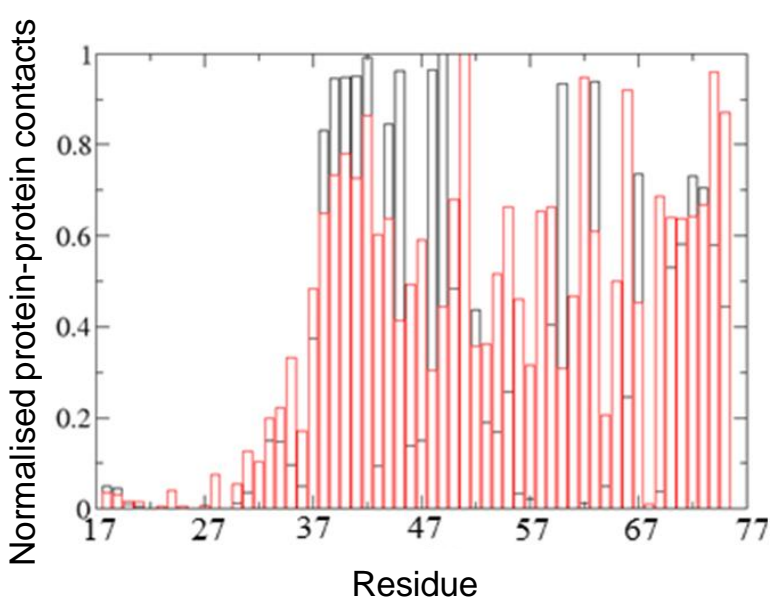

$\mathrm{N}$-terminus: rigidified

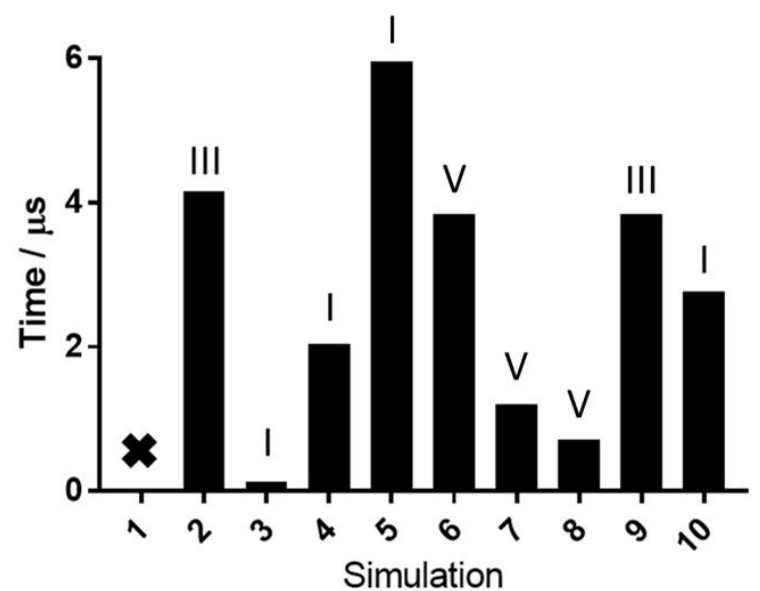


bioRxiv preprint doi: https://doi. org/10.1101/2021.03.11.435022; this version posted March 12 2021. The copyright holder for this preprint (which was not certified by peer review) is the author/funder, who has granted bioRxiv a license to display the preprint in perpetuity. It is made available under aCC-BY-NC-ND 4.0 International license.

A
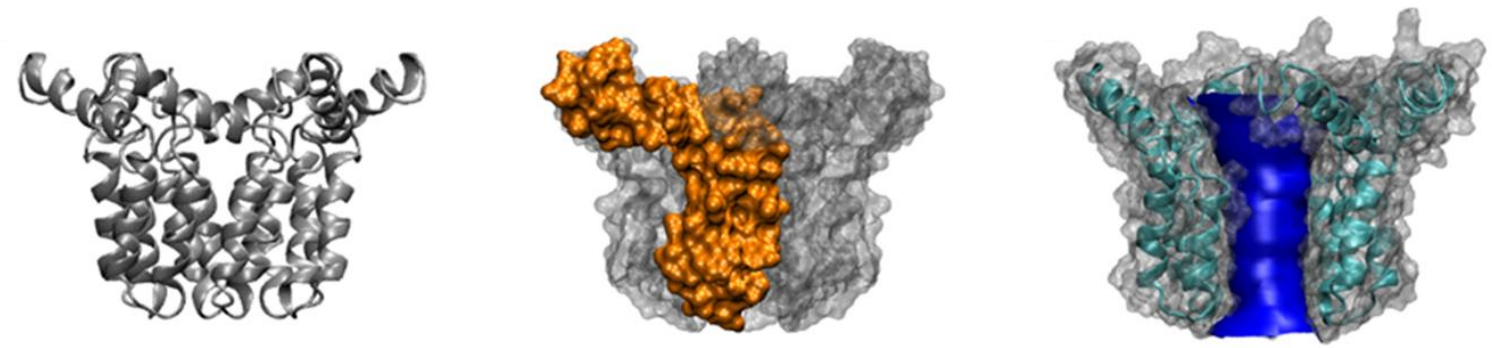

Figure 6
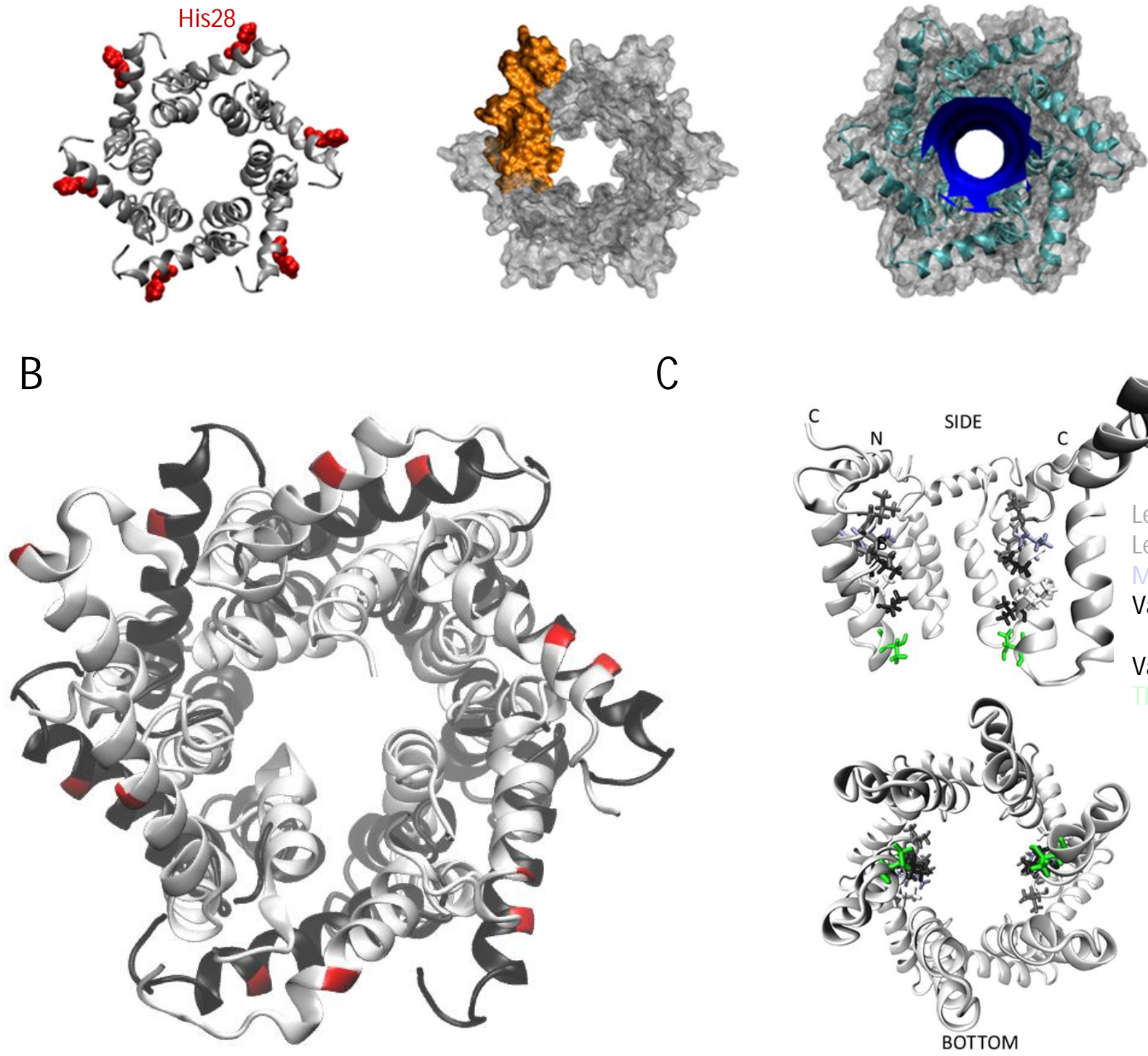
bioRxiv preprint doi: https://doi org/10.1101/2021.03.11.435022; this version posted March 12 2021. The copyright holder for this preprint (which was not certified by peer review) is the author/funder, who has granted bioRxiv a license to display the preprint in perpetuity. It is made available under aCC-BY-NC-ND 4.0 International license.

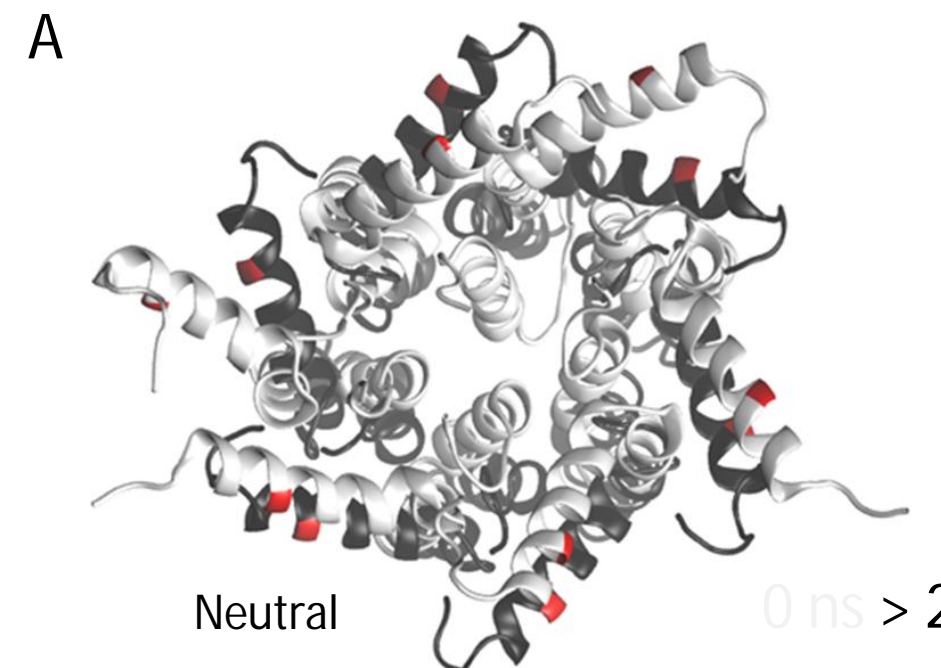

$\mathrm{B}$

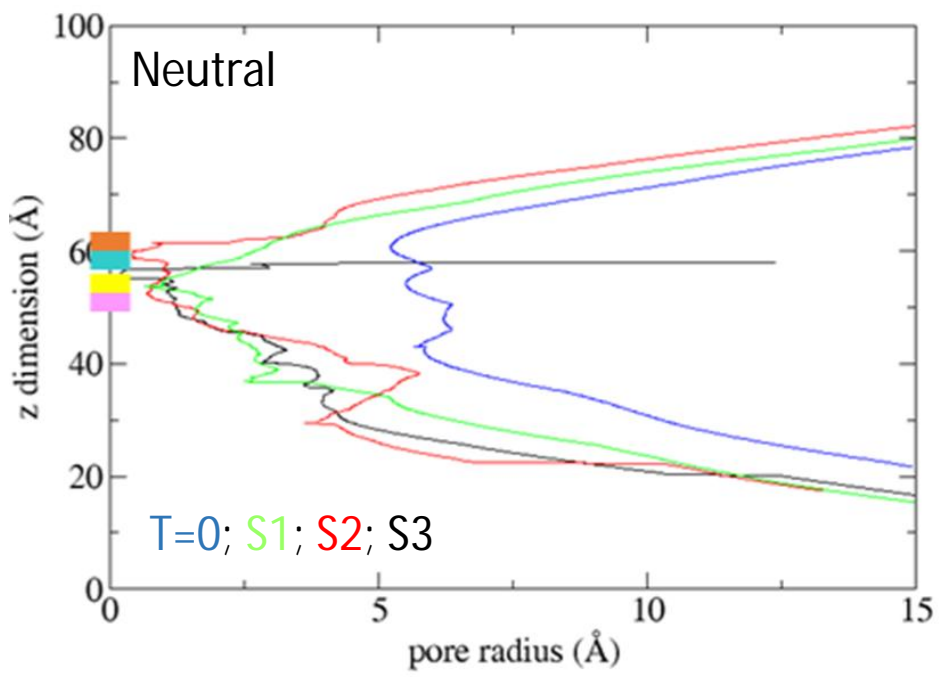

$\mathrm{C}$

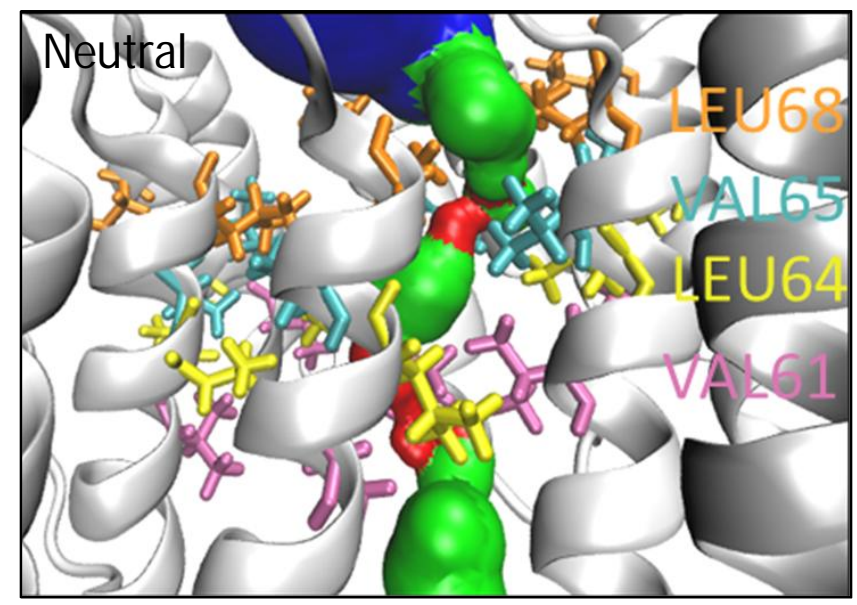

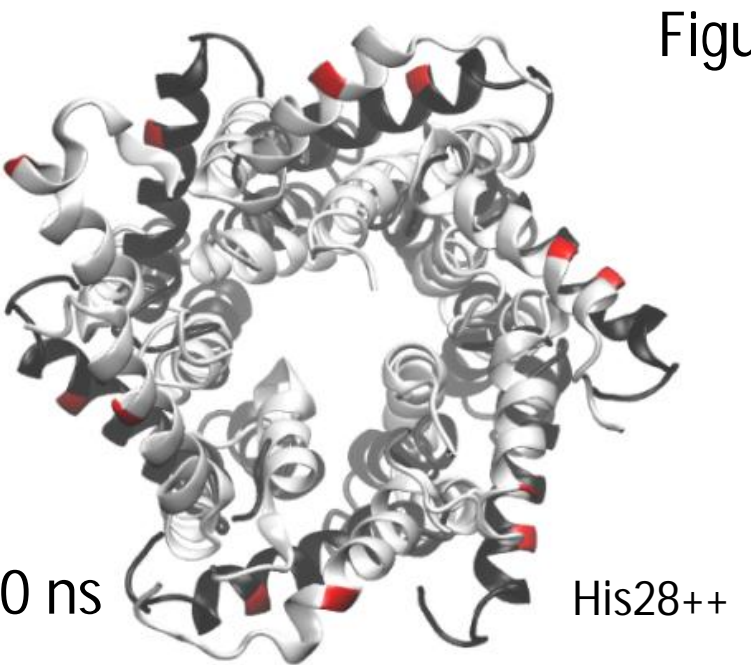

Figure 7
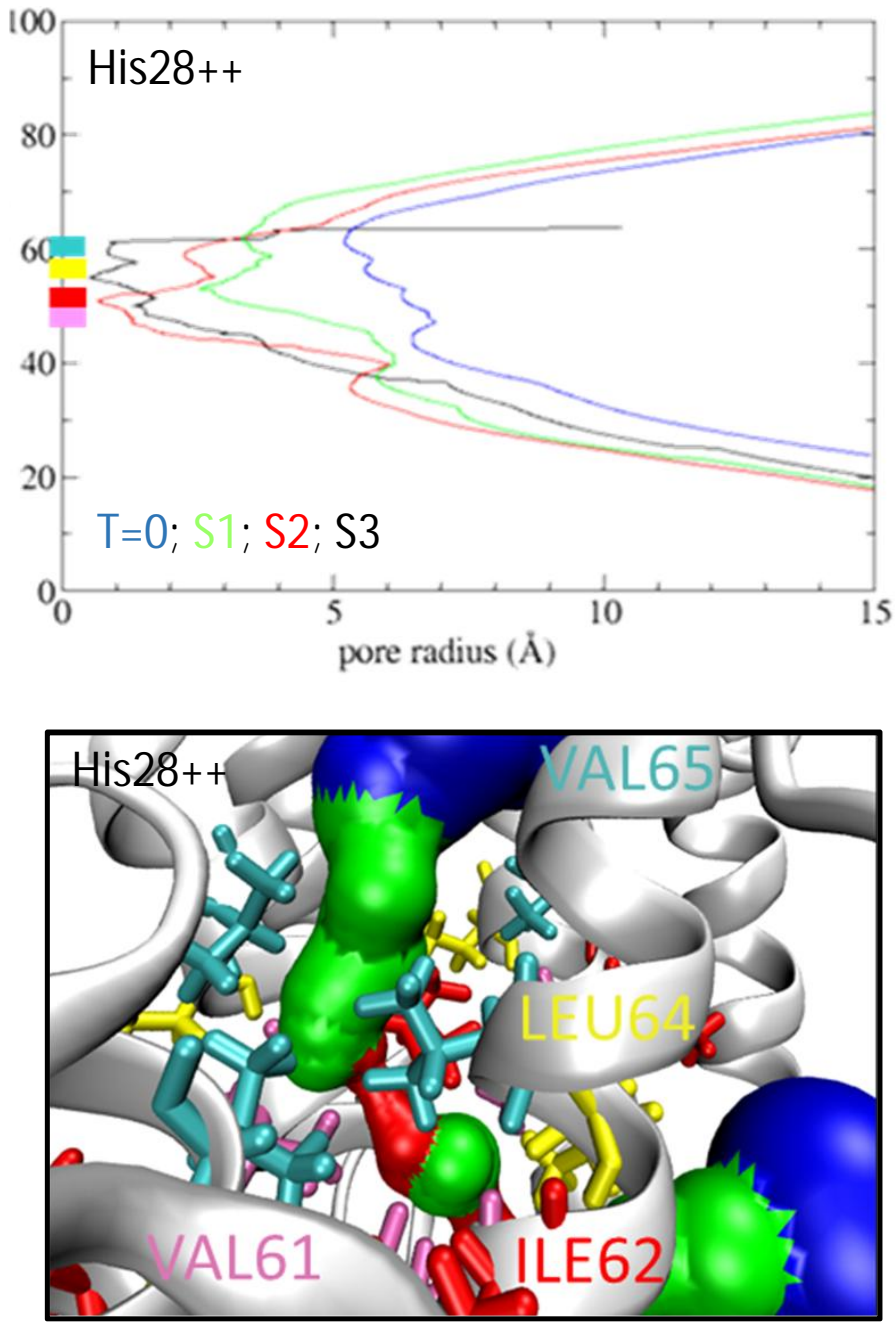

D
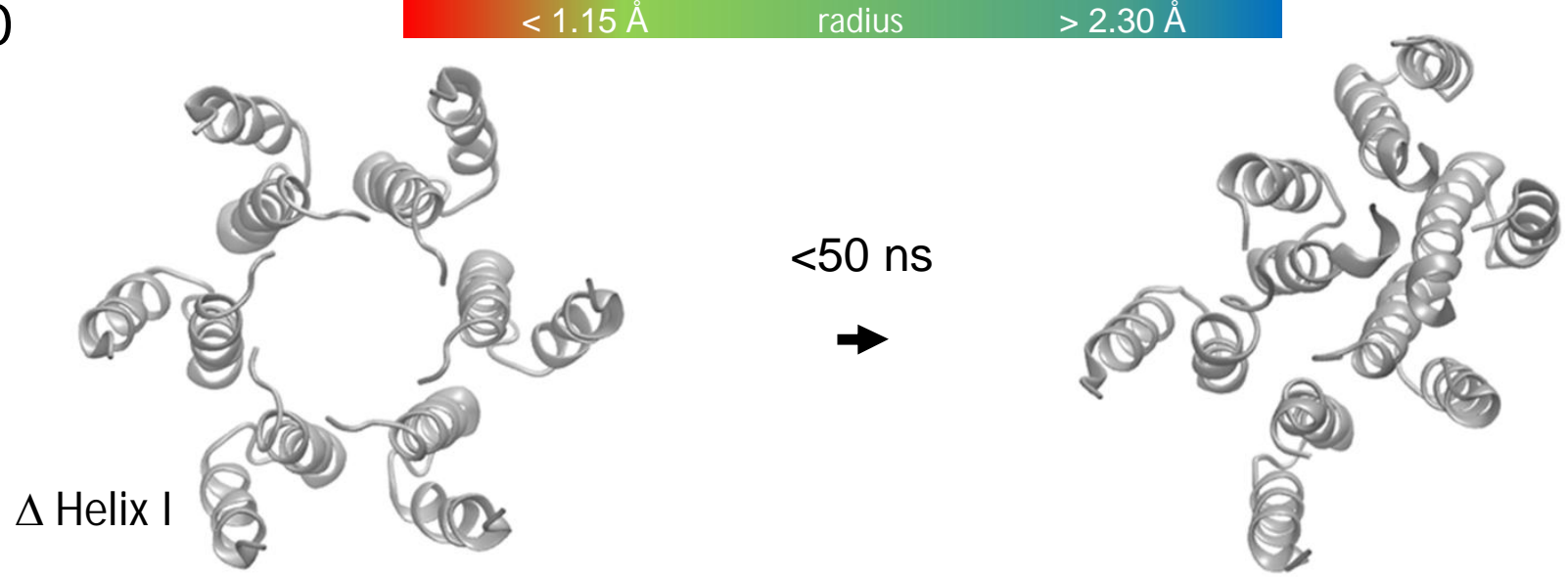
bioRxiv preprint doi: https://doi.org/10.1101/2021.03.11.435022; this version posted March 12, 2021. The copyright holder for this preprint (which was not certified by peer review) is the author/funder, who has granted bioRxiv a license to display the preprint in perpetuity. It is made available under aCC-BY-NC-ND 4.0 International license.

Figure 8

A
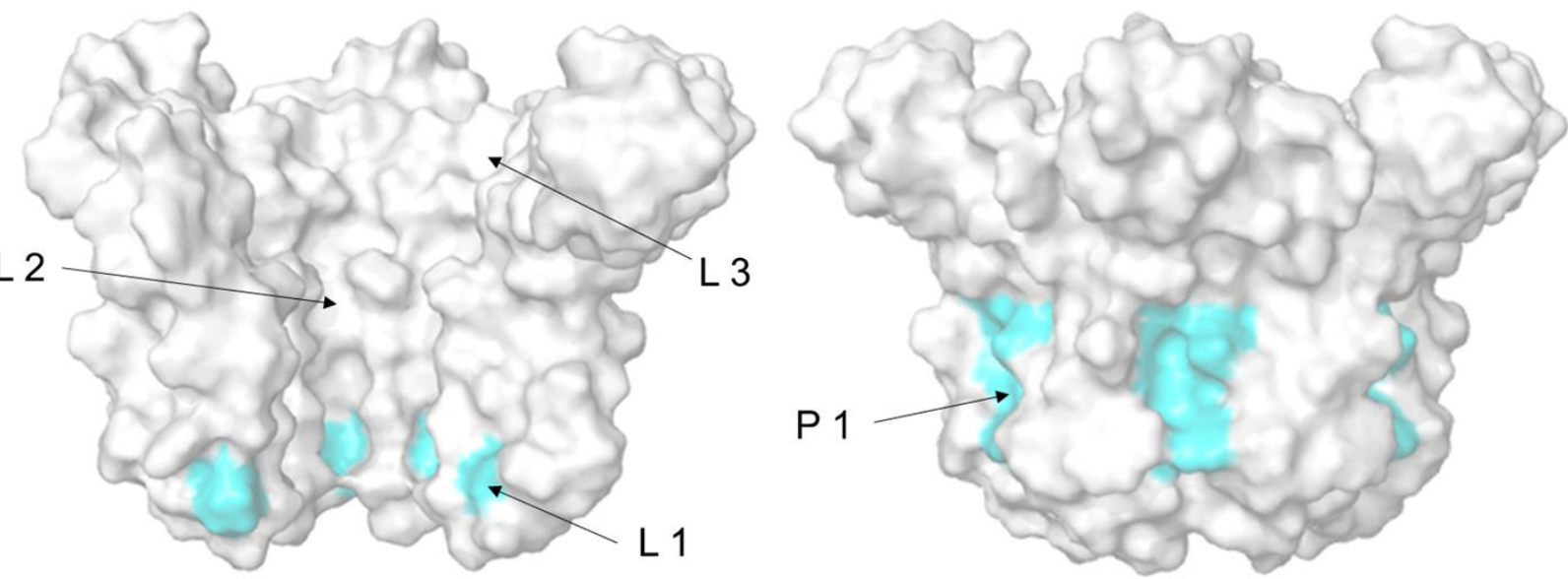

B

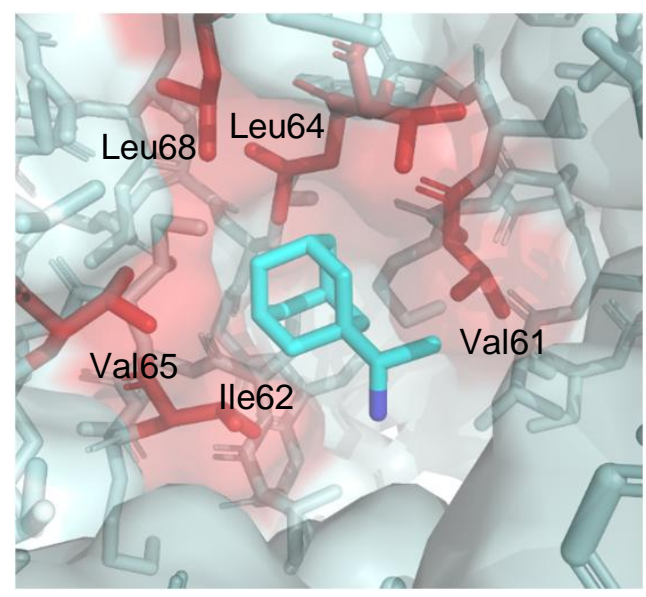

C

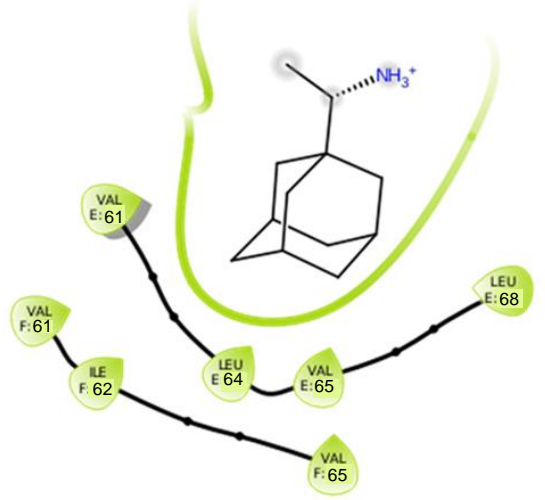

Hydrophobic
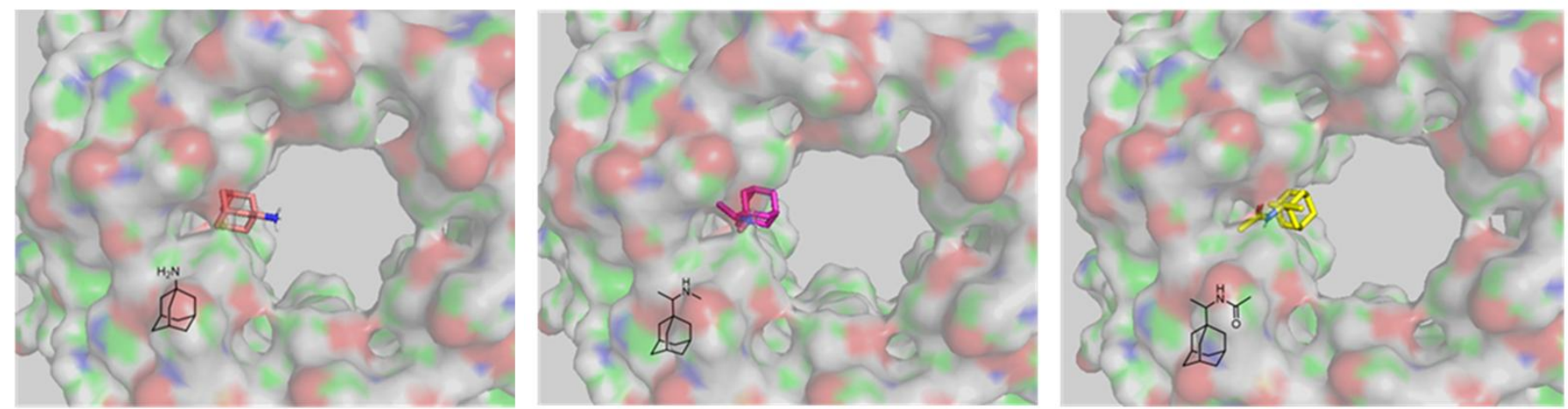

D

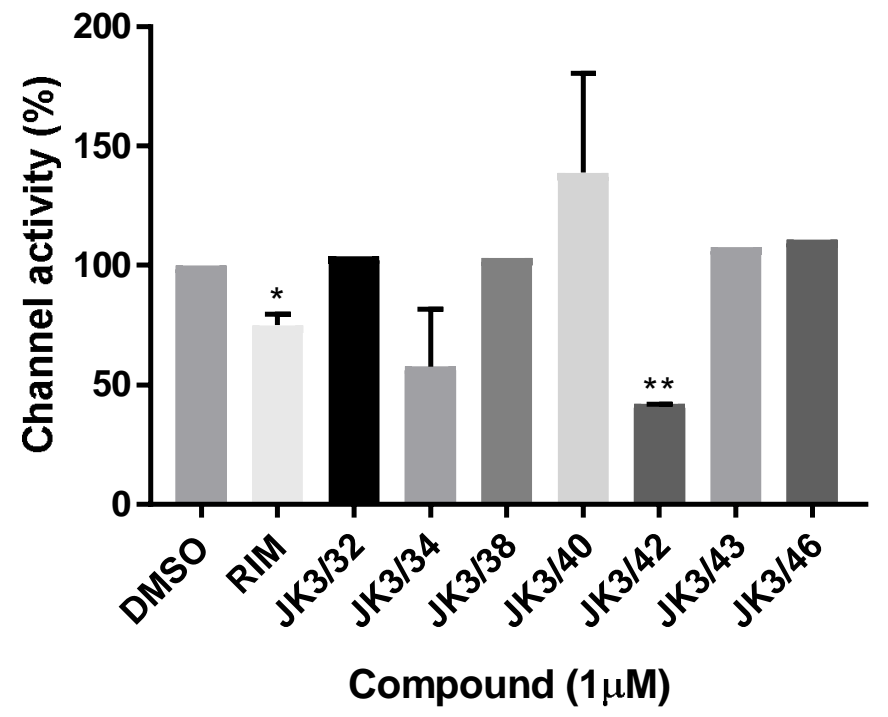<smiles>COc1ccc(C(=O)Cn2nc(-c3ccccc3)c3ccccc3c2=O)cc1</smiles>

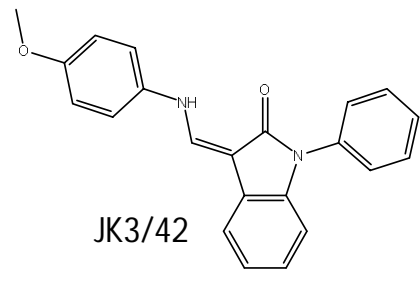


bioRxiv preprint doi: https://doi org/10.1101/2021.03.11.435022; this version posted March 12, 2021. The copyright holder for this preprint (which was not certified by peer review) is the author/funder, who has granted bioRxiv a license to display the preprint in perpetuity. It is made available under aCC-BY-NC-ND 4.0 International license.

A

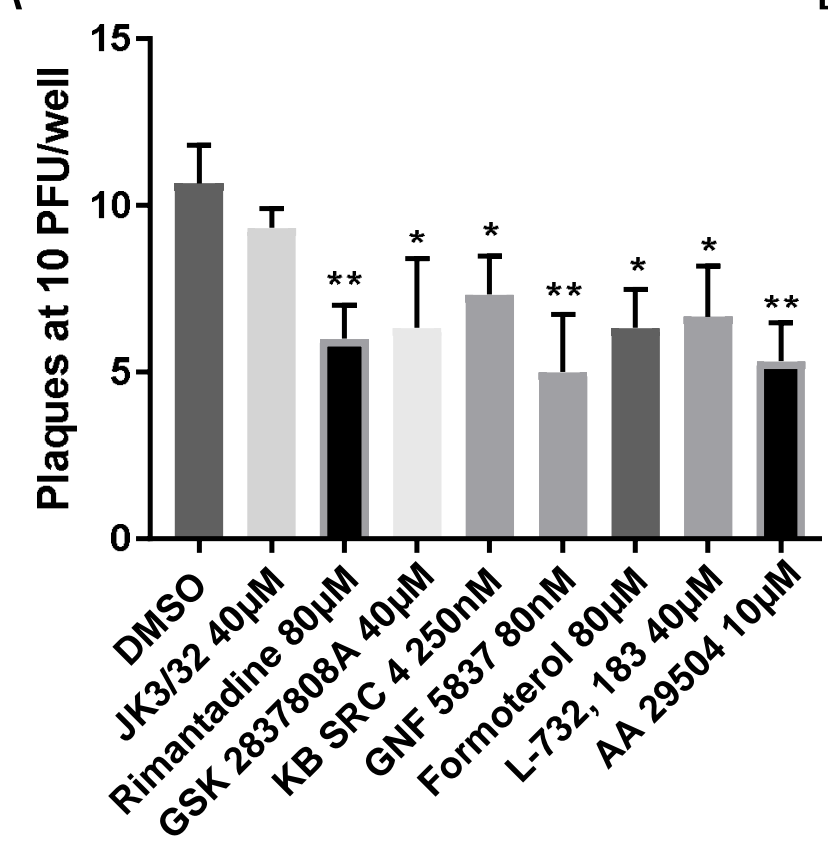

C

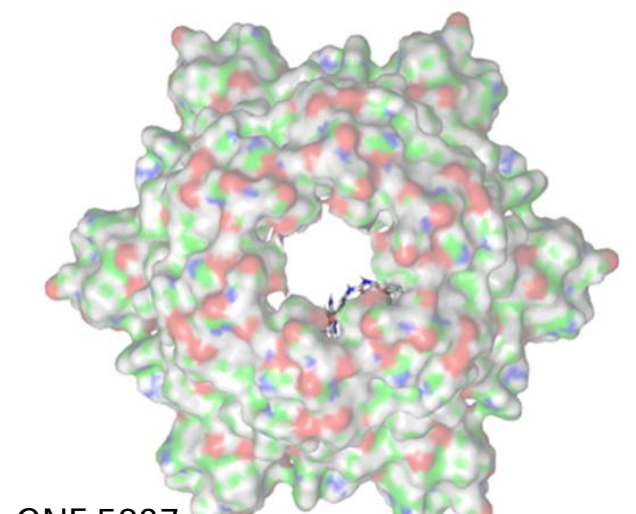

GNF 5837

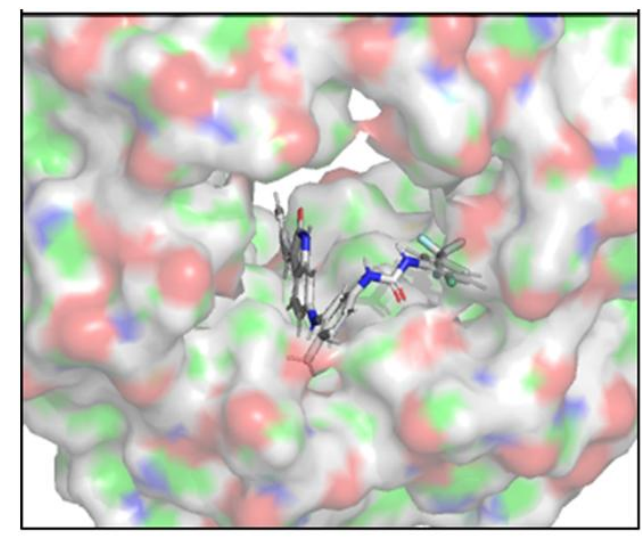

D

8 胥

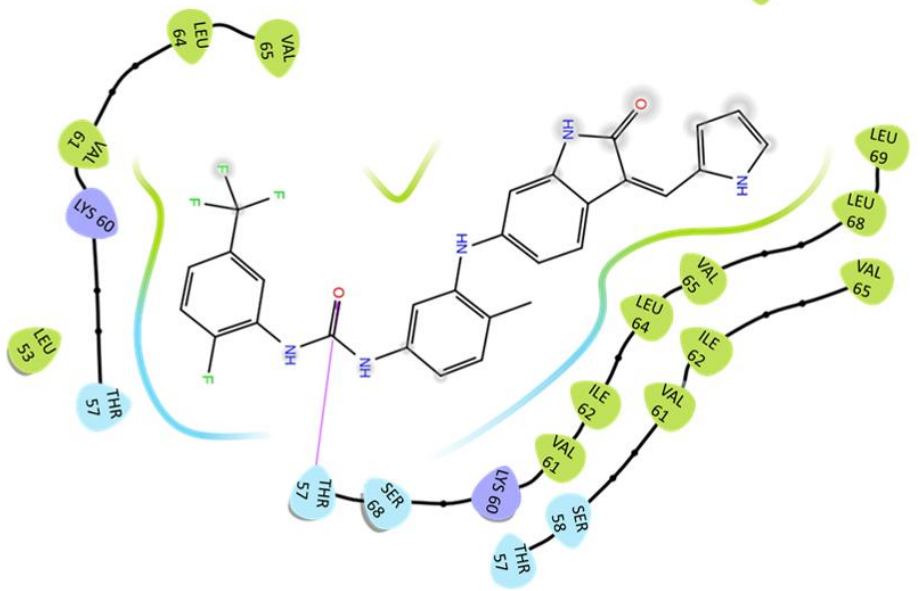

$B$

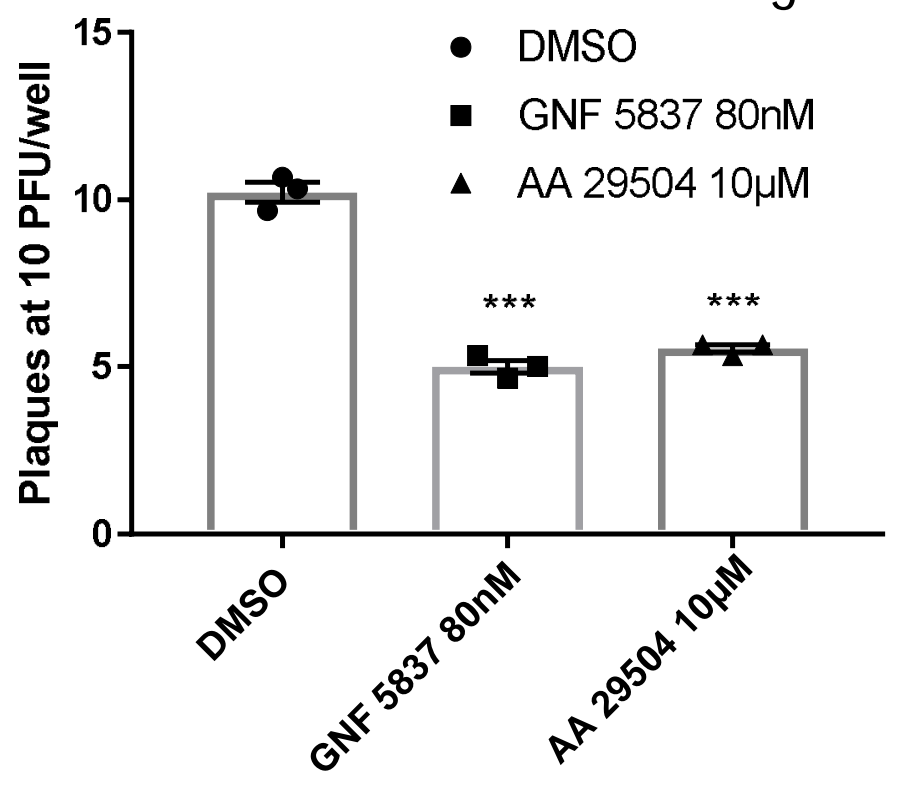

$E$

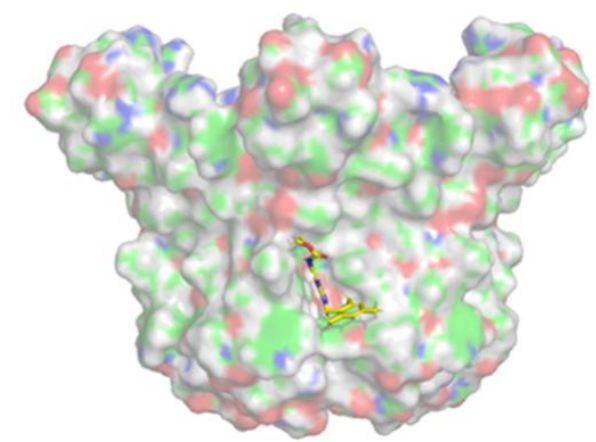

AA 29504

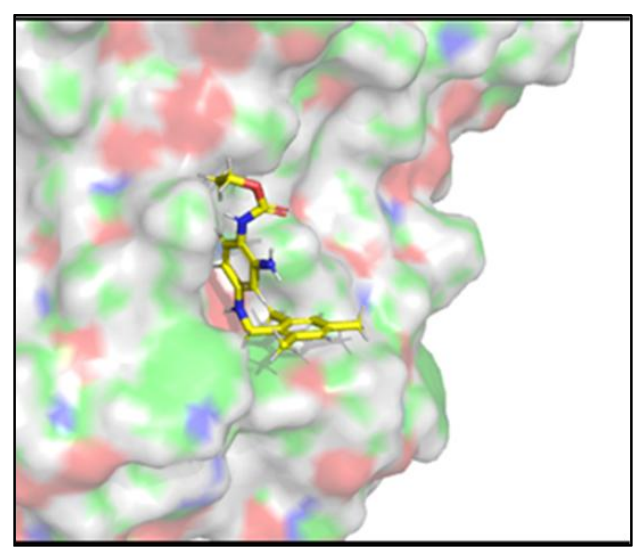

F

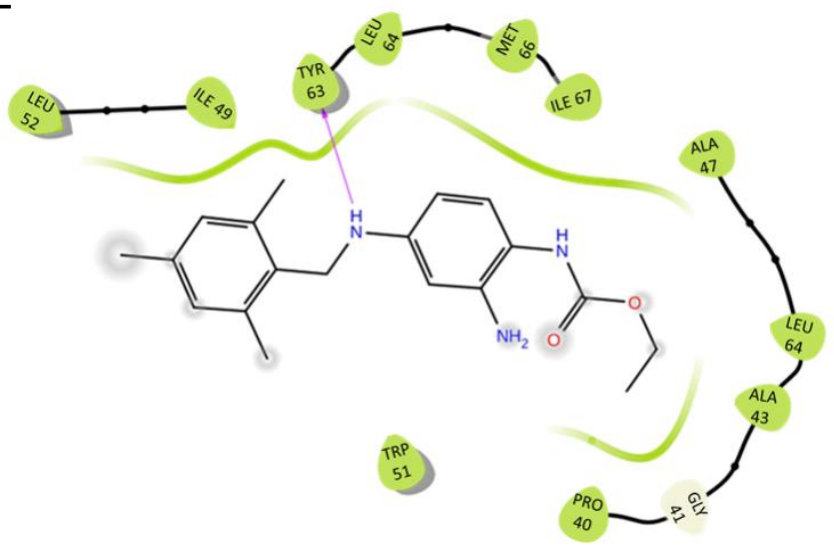


A

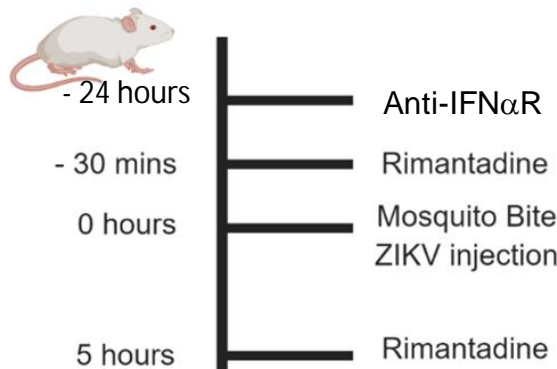

24 hours

Samples collected
B

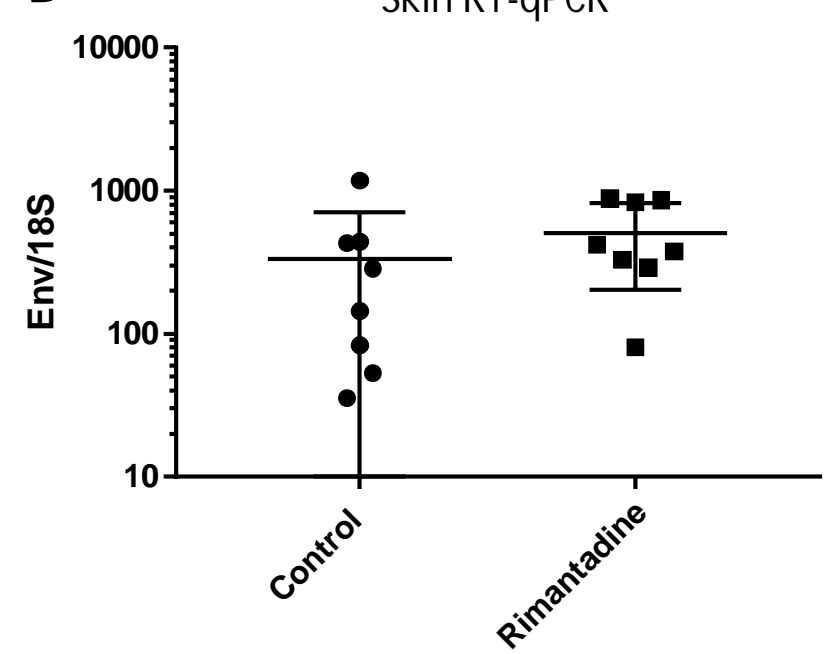

C

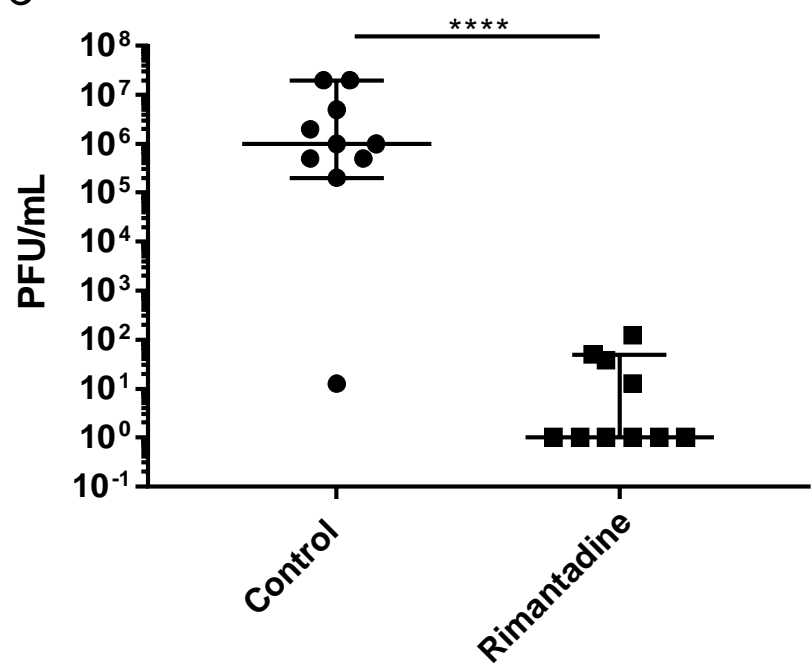

